\title{
THE 2008-2009 EXCAVATIONS AT THE SAC LOCALITY, REBER-RAKIVAL LAPITA SITE, WATOM ISLAND, PAPUA NEW GUINEA
}

\author{
Peter Petchey ${ }^{1}$, Hallie Buckley ${ }^{2}$, Richard Walter ${ }^{1}$, Dimitri Anson ${ }^{1}$, Rebecca Kinaston ${ }^{2}$ \\ ${ }^{1}$ Department of Anthropology and Archaeology, University of Otago, ${ }^{2}$ Anatomy Department, University of Otago
}

\begin{abstract}
The Reber-Rakival site on Watom Island is of particular significance, as it is the first place where what is now known as Lapita pottery was found, by a German missionary in 1909. It is also significant as a Lapita-era burial site, although there has been much debate about the exact relationship between the burials and the Lapita occupation. In 2008 and 2009 an Otago University/Otago Museum/Papua New Guinea National Museum expedition carried out new excavations at the SAC locality in Rakival Village, in order to increase the sample size of both burials and ceramics, and to address some of the ongoing debates. The expedition found more burials, Lapita ceramics and associated artefactual material, and while it confirmed the relationship between the burials and the Lapita occupation, it also found that previous excavations had not reached the base of the site, and evidence of human occuption was found up to $0.8 \mathrm{~m}$ deeper than previously known. Based on this work, a refined stratigraphic sequence is presented, with 7 layers replacing the old 4 zone model that has been used to date. This paper presents the description and interpretation of the SAC locality at Watom, and provides a basis for other more specialist papers that are in preparation.
\end{abstract}

\section{INTRODUCTION}

The Reber-Rakival site is located on Watom Island in East New Britain Province, Papua New Guinea, within the Bismark Archipelago (Figures 1 \& 2) (Reber is the name of the mission station, Rakival is the village). It is a key site in the history of archaeological investigations into the Lapita cultural complex, as it is the first site at which what is now known as Lapita pottery was found. Dentatestamped pottery, accompanied by the introduction of horticultural plants and domesticated animals (pigs, chickens and possibly dogs), is the distinctive material signature of the first Austronesian populations to discover and settle 'Remote Oceania' (Southern Melanesia and Western Polynesia) (Pietrusewsky et al. 2014; Sande 1998: 7; Specht 1968: 117). In 1909 the German missionary at the village, Father Otto Meyer, carried out a series of excavations and published his results, including illustrations of the decorated pottery sherds that he found (Meyer 1909a, 1909b, 1910). Further excavations were carried out by archaeologists Specht, Anson and Green in the 1960s and 1980s at several locations within the overall site area (Anson et al. 2005; Green 2000; Specht 1968). In addition, until the discovery of the Teouma site in Vanuatu (Bedford et al. 2006; Bedford et al. 2009), it was regarded as the largest Lapita cemetery site known. In 2008 and 2009 a two-season excavation project was undertaken at the SAC locality at Reber-Rakival under the direction of Dr. Dimitri Anson (then of the Otago Museum) and Ass. Prof. Hallie Buckley (University of Otago). This paper describes the new excavations at the SAC locality (SAC is the Papua New Guinea National Museum code for the specific location) and presents a refined and revised stratigraphic sequence for this unit. It is of necessity very descriptive, as it provides the stratigraphic framework for other more specialist research currently being carried out on different aspects of the 2008-09 excavations.

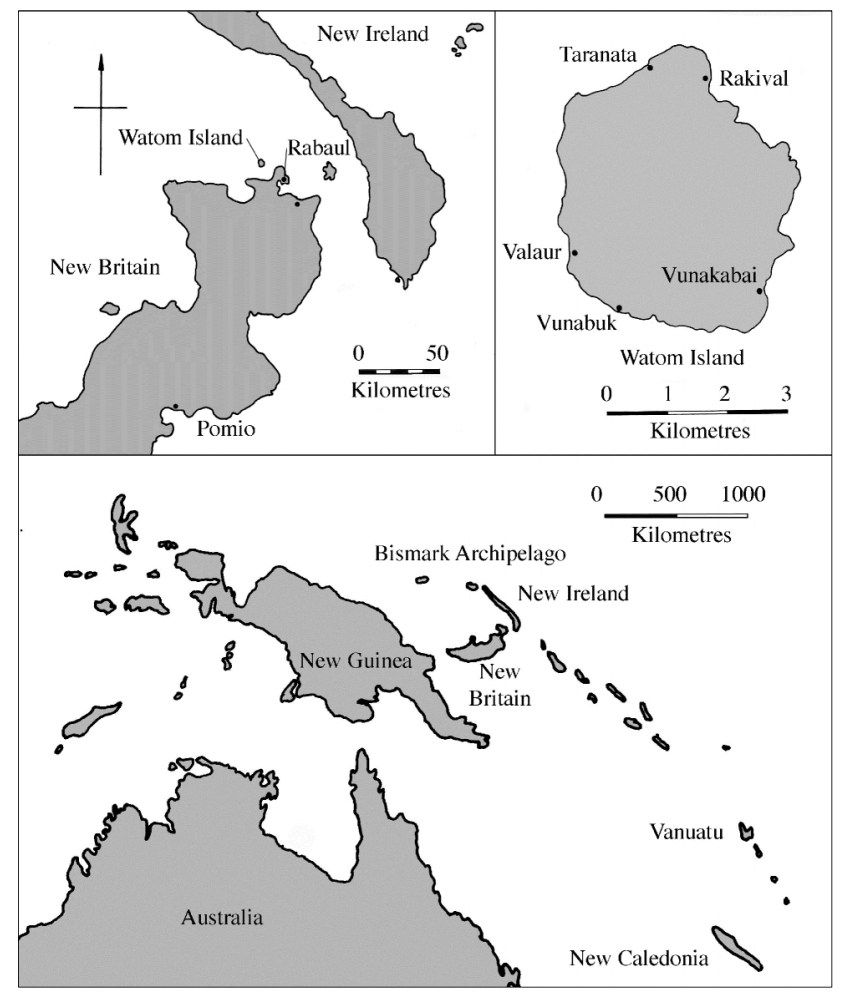

Figure 1: Location of Watom Island. 


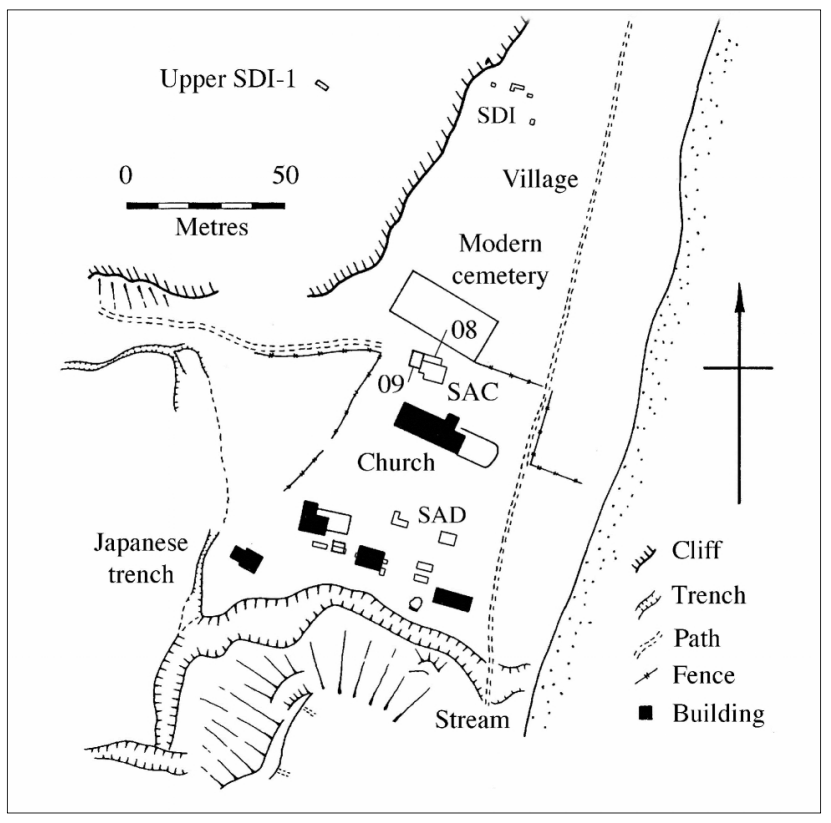

Figure 2: Rakival Village and the location of the 2008 and 2009 SAC excavations.

\section{PREVIOUS RESEARCH}

In 1909 Father Otto Meyer carried out a series of excavations in the vicinity of the Reber Mission Station in Rakival village and found ceramics with what he termed 'designs' that are now recognised as 'Lapita,' and ceramics with appliqué decoration that he termed 'Melanesian' (Meyer 1909a, 1909b, 1910). In 1966-67 Jim Specht carried out a series of further investigations at ReberRakival, and found burials and associated Lapita ceramics at Kainapirina (his Site 8, now identified as SAC). At the same time a series of auger holes were dug around the site by C.A. Key. Specht identified a distinct stratigraphic sequence that he labelled Zones $\mathrm{A}$ to $\mathrm{C}$, with the main cultural occupation context in Zone $\mathrm{C}$ (divided into $\mathrm{C} 1$ and $\mathrm{C} 2$ ). Three burials were found in Zone $\mathrm{C} 2$ and bone from these individuals provided a radiocarbon date of ca. 500 BC (ANU-37b) (Specht 1968, 2003).

In 1985 Roger Green and Dimitri Anson revisited Watom as part of the Lapita Homeland Project, and relocated and extended Specht's Site 8 (SAC) excavation. They described the same straigraphic sequence as reported by Specht, and continued to use his 'Zone' nomenclature. They recovered five more burials (Burials 4-8) from the same stratigraphic context (Zone $\mathrm{C} 2$ ), all in flexed positions. Lapita ceramics fragments were found in both Zones C1 and C2, while nail-impressed and applied relief ceramics were only found in Zone C1. Dates for the SAC site indicated that it was occupied from ca. 2700 BP up until ca. 2190-1730 BP (see Anson et al. 2005: 37-39 for details).

There has subsequently been an ongoing debate regarding the dating and stratigraphic context of the Lapita occupation and burial context at Watom. One line of questioning has considered the SAC dates as too recent for the generally accepted range of Lapita, and that the $\mathrm{C} 1 / \mathrm{C} 2$ stratigraphy is in reality badly disturbed (Best 2002: 88-89; Garling 2007: 56, 68-69; see also Anson et al. 2005: 10-16 for a detailed discussion of the debate).

\section{RESEARCH AIMS OF 2008-2009 EXCAVATIONS}

The 2008/09 excavation at SAC was part of a larger research project at Reber-Rakival that had several goals, and included numerous test excavations as well as the main SAC unit. The overall research aims were to:

Enlarge the SAC excavation area in order to increase the burial sample size for further macroscopic and chemical analysis and in particular to compare the Watom burials with the burials from the recently-discovered Lapita cemetery at Teouma in Vanuatu (Bedford et al. 2009).

Address the debate about the stratigraphic context of Lapita ceramics and occupation at the SAC unit.

Enlarge the area excavated at the SDI location to further study the relationship between the Lapita cultural complex and its successors.

To locate the archaeological deposits from which the fine, large fragments of Lapita pottery found by Father Meyer originated.

\section{THE 2008-2009 EXCAVATION OF SAC}

The excavations of SAC were carried out in February 2008, and May-June 2009. The 2008 excavation unit was a $2 \mathrm{~m}$ by $5 \mathrm{~m}$ area running east-west, and the 2009 unit measured $5 \mathrm{~m}$ by $4 \mathrm{~m}$ running north-south. Both units were adjacent to the 1985 excavation, and the earlier square numbering system was continued (Figure 3). Excavation was carried out in $100 \mathrm{~mm}$ spits, except when bulking out the culturally sterile volcanic ash layer, when $200 \mathrm{~mm}$ spits were employed, and when cleaning down to an actual layer surface. In 2009 a $1 \mathrm{~m}$ by $1 \mathrm{~m}$ excavation into the 1985 excavation backfill was also removed to allow Burial 15 to be recovered, as the 1985 excavation had stopped before this burial was reached.

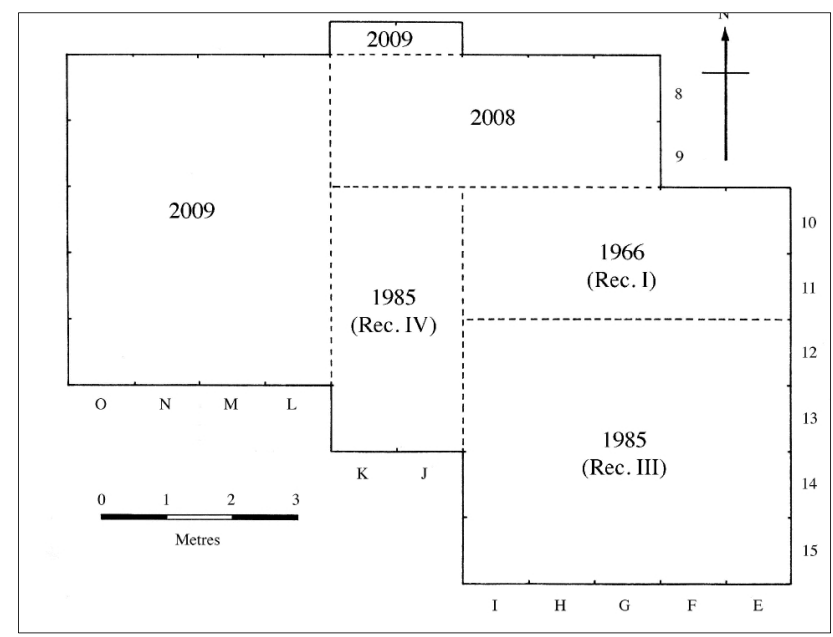

Figure 3: Relationship of 2008 and 2009 SAC excavations to earlier excavations. 


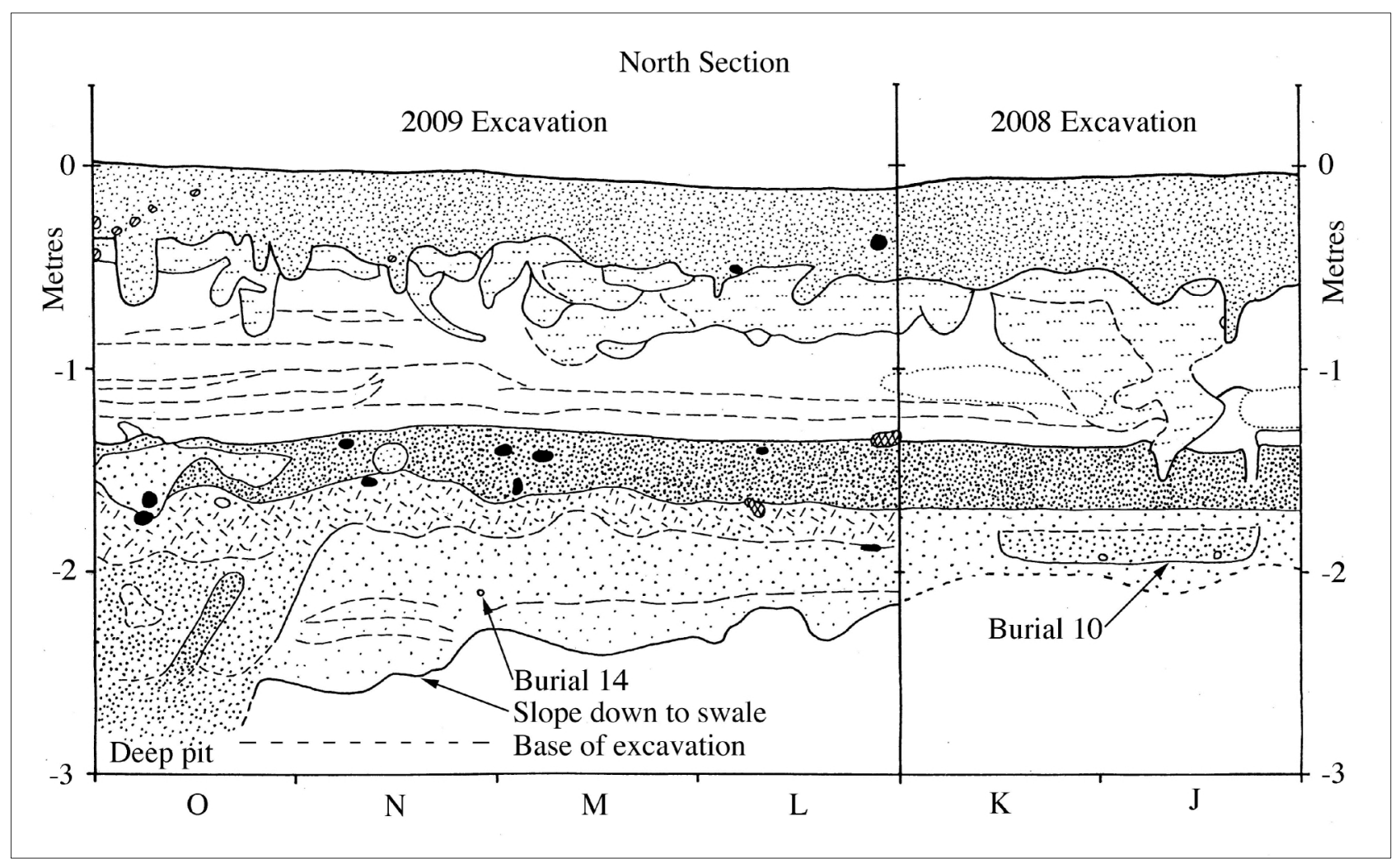

Figure 4: North section SAC 2009.

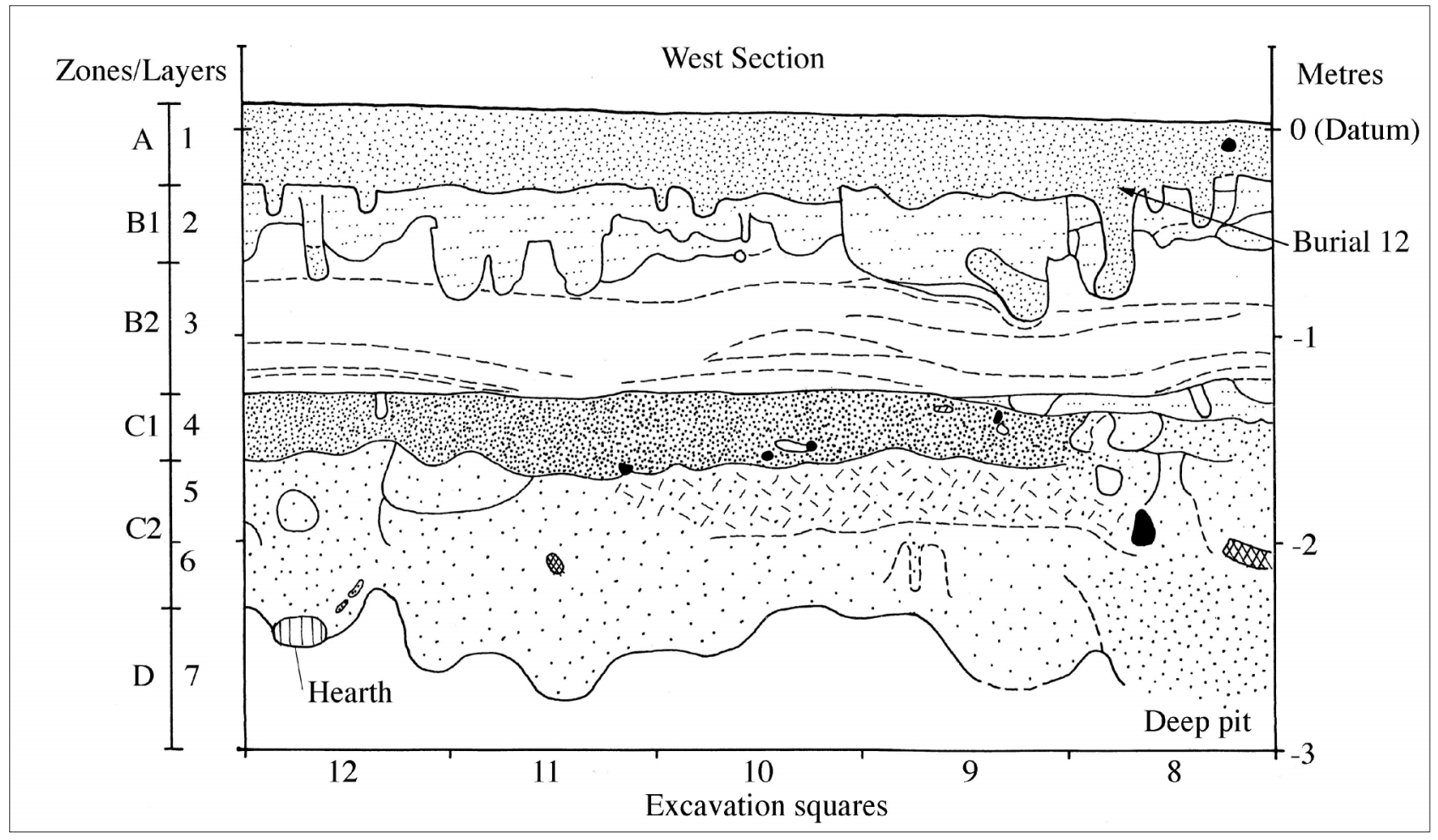

Figure 5: West section SAC 2009. 


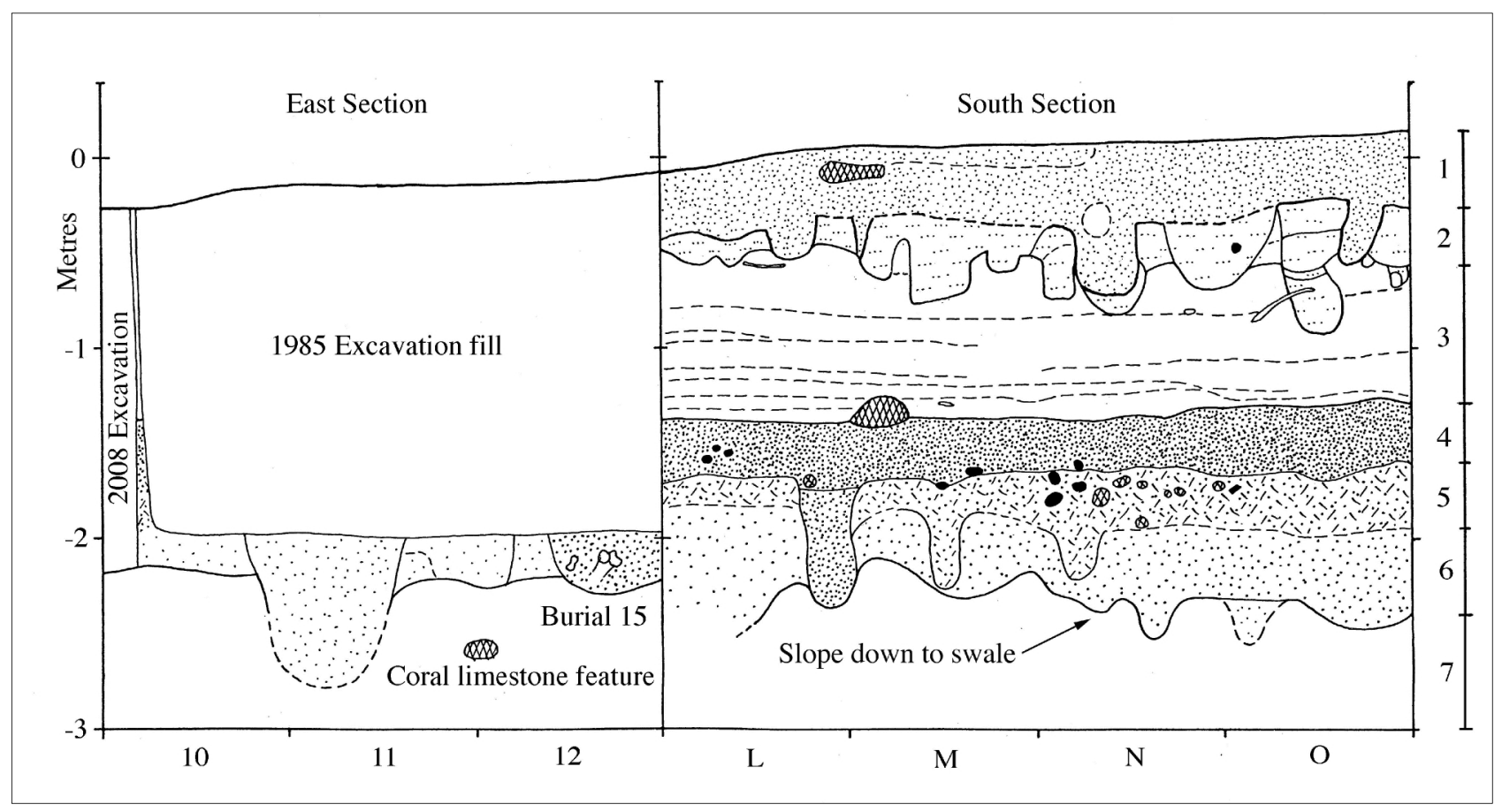

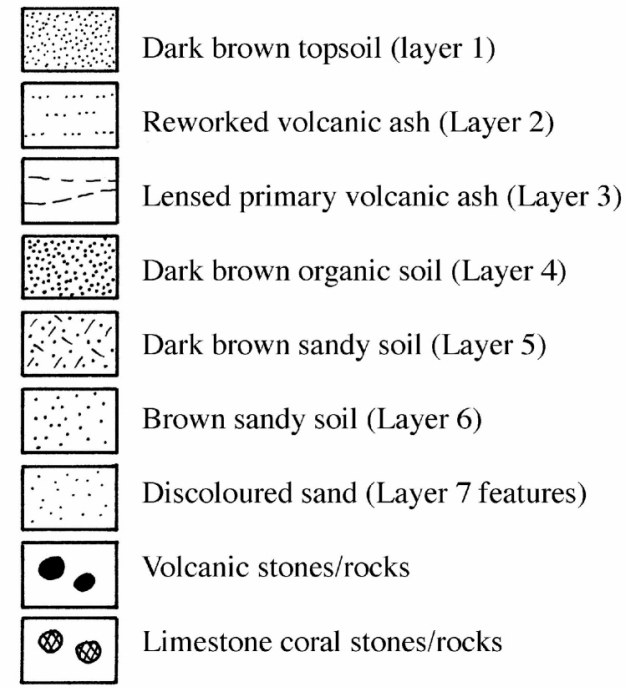

Figure 6: South and East sections SAC 2009 and key to symbols used in plans and sections.

On site all material was passed through coarse screens $(11.5 \mathrm{~mm})$ to remove the larger coral fragments and faunal and artefactual material was recovered at this stage and bagged according to $100 \mathrm{~mm}$ spit, layer and $1 \mathrm{x} 1 \mathrm{~m}$ horizontal unit. On reaching Layer 4 , the high organic content and wet, dense soil matrix raised the risk of losing material without the facility for bulk wet-sieving. To provide quantitative control over the midden sample a bulk sample was collected from each spit, wet sieved through $3 \mathrm{~mm}$ screens and retained for analysis. The bulk sample comprised a column sample for Units $\mathrm{O} 12$ and
M8 from Layer 4 through to Layer 7 (Zones C to D, see below for a discussion of the layers).

The general stratigraphic sequence that was encountered was as described by Meyer (1909, quoted in Green 2000) and refined by Specht (1968) and Green \& Anson (2000). This consisted of four main 'zones,' namely a topsoil layer (Zone A), an ash layer (Zones B1 \& B2), a cultural layer buried by the ashfall (Zones C1 \& C2) and a beach sand layer (Zone D). In particular the very definite breaks between Zones $\mathrm{B} 2$ and $\mathrm{C} 1$, and $\mathrm{C} 1$ and $\mathrm{C} 2$ were again observed. During the 2008 and 2009 field seasons this same nomenclature was used to ensure consistency. We now propose a revision of the SAC stratigraphic sequence, based primarily on the findings of the 2009 excavation season.

The 2009 excavation showed that there was greater stratigraphic complexity within the sequence than had previously been described. The Zone B1 volcanic ash layer that had earlier been described as redeposited ash with a few pits and post holes cut down from Zone A (Anson et al. 2005: 6, 34; Green \& Anson 2000: 40), was reinterpreted as the product of a great deal of human activity as people reoccupied the post-eruption landscape, with a large number of pits and post holes. It is probably better described as reworked ash, and a cultural layer in its own right. The Zone $\mathrm{C} 2$ cultural horizon could be split into two layers, and there was evidence of cultural activity in the Zone D sands that had previously been considered sterile, which extended the identified cultural material up to $800 \mathrm{~mm}$ deeper than previously reported.

Our revised stratigraphic interpretation (illustrated in the 2009 sections, Figures 4-6) is as follows. Seven cultural layers (Layers 1-7) can be correlated with the more general previously published sequence (Zones A to D). Table 1 summarises the old and new sequences and their 
relationships. This refined sequence is similar to the published sequence for the SDI locality on Watom, in which four ' $C$ ' horizons were identified (Anson et al. 2005: 9).

Table 1: Summary of SAC stratigraphic sequence.

\begin{tabular}{lll}
\hline $\begin{array}{l}\text { Layer } \\
\text { (current interpre- } \\
\text { tation) }\end{array}$ & $\begin{array}{l}\text { Zone } \\
\text { (Anson et } \\
\text { al. 2005) }\end{array}$ & Description \\
\hline 1 & A & $\begin{array}{l}\text { Topsoil, with modern \& historic } \\
\text { activity evidence } \\
\text { Culturally modified ash. Pits \& post } \\
\text { holes, including one structure } \\
\text { alignment. }\end{array}$ \\
2 & B1 & $\begin{array}{l}\text { Sterile volcanic ash } \\
3\end{array}$ \\
4 & B2 & $\begin{array}{l}\text { Dark organic soil, scattered Lapita } \\
\text { fragments } \\
\text { Sandy soil with coral frags, burials, } \\
\text { Lapita frags. } \\
\text { Sandy soil, stone alignments, } \\
\text { burials, Lapita frags. } \\
\text { Some cultural activity dug into } \\
\text { clean sand. Evidence of earliest } \\
\text { activity at the site. }\end{array}$ \\
\hline
\end{tabular}

\section{Layer 1 (Zone A)}

The topsoil layer (Layer 1) was a very dark organic sandy soil, with some shell and coral inclusions. On average the layer was $400 \mathrm{~mm}$ deep. Some small pits and possible post holes were found within Layer 1, with many more being identified where they cut down into Layer 2 . In the north-west corner of the unit a child burial (Burial 12) was found.

Artefactual material in Layer 1 included obsidian flakes and a stone adze fragment, together with modern material such as bottle and window glass, a clay pipe fragment and two .50 calibre bullets. The latter date from World War Two, when the Japanese military occupied the island (Petchey 2015; Specht 1968). Anson et al. (2005: 35 ) mention the presence of early historic trade goods in this layer in earlier excavations.

\section{Layer 2 (Zone B1)}

Layer 2 consisted of a reworked yellow/brown ash, with numerous pits and postholes. The depth of the layer varied due to the pits and holes cut down into Layer 3, but it was generally between $200 \mathrm{~mm}$ and $500 \mathrm{~mm}$ thick. Features were both cut down from Layer 1 into Layer 2, and from Layer 2 down into Layer 3. The surface of Layer 2 in the 2009 excavation had 50 identified cut features (although at times it was difficult to determine cultural pits from crab burrows). In particular there was a post-hole alignment running almost north-south along the western edge of the unit (Figure 7), representing a structure such as a fenceline.

This layer represented the human re-occupation of the site after the ash fall from the Rabaul eruption of ca. 1400 BP (Walker et al. 1981, quoted in Anson et al. 2005). The soil formation processes probably included friable ash being washed down from the hill country (secondary deposition as discussed by Anson et al. 2005: 6, 34), together with the inevitable detritus accumulation from human activity. However, the lack of artefactual material from this layer was notable given the number of cultural features.



Figure 7: The surface of Layer 2.

\section{Layer 3 (Zone B2)}

Layer 3 consisted of undisturbed naturally deposited volcanic ash from the Rabaul eruption of ca. $1400 \mathrm{BP}$ (Walker et al. 1981, quoted in Anson et al. 2005: 34). Bands of fine friable ash were interspersed with some coarser ash and pumice lenses. The ash layer was between $500 \mathrm{~mm}$ and 1 metre thick, the variation being due to pits and holes cut down from Layer 2. Apart from one area of disturbance in the north-west corner of the 2009 SAC unit (the deep pit feature discussed further below) and one small area in the 2008 excavation, this Layer 3 ash sat cleanly on the surface of the Layer 4 (Zone C1) soil, with no other intermixing observable.

\section{Layer 4 (Zone $\mathrm{C} 1$ )}

Layer 4 was a very dark organic soil, between $200 \mathrm{~mm}$ and $400 \mathrm{~mm}$ thick, that has been interpreted as a garden soil (Anson et al. 2005: 9). The surface that was exposed after the Layer 3 ash was removed was undulating, with several large (approx. 300mm long) rocks and a scatter of smaller stones sitting on the soil surface, together with a fragment of pig bone (Figure 8). This was a relict surface, preserved when the volcanic ash began to fall. At the SDI locality pockets of charcoal on top of this surface were interpreted as the remains of vegetation burnt at the time of the eruption (Anson et al. 2005: 34).

In the north-west corner of the 2009 SAC unit there was an area of disturbance, probably a pit feature, that 
was completely sealed above by the Layer 3 ash. This disturbance extended down from Layer 4 to Layer 7 (most easily identified in the section drawings, Figures $4 \& 5$ ), and is discussed in more detail below. Several other smaller pits extended down into Layer 5 (Zone C2).

The quantity of cultural material in Layer 4 increased with depth as the layer was excavated. This material included ceramic fragments (both patterned and plain), obsidian, a file or abrader, an adze fragment and pig bone fragments. This material is discussed further below. There were also numerous fragments of human bone and teeth, although none were in association with any burial features. This material was probably derived from Layer 5 (Zone C2) burials that were cut into by later Layer 4 gardening activity (see Anson et al. 2005: 11).

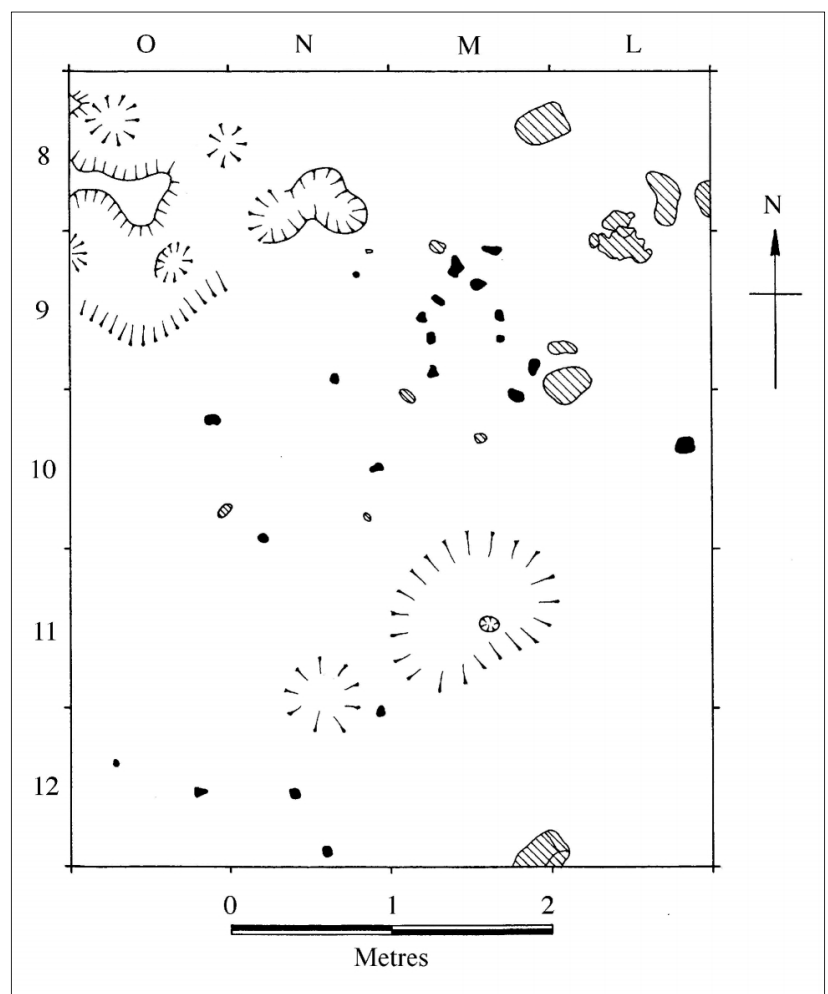

Figure 8: The surface of Layer 4.

\section{Layer 5 (Zone C2 upper)}

Layer 5 consisted of a dark brown soil matrix with a distinctive grey flecking due to a large content of sand and fragmented coral. It was visually and by feel distinct from the darker, more organic, Layer 4 matrix. The layer varied in thickness, but was typically $200 \mathrm{~mm}$ to $400 \mathrm{~mm}$ deep. The surface of Layer 5 was quite undulating, with a scatter of stones, and the bases of a number of pits and post holes cut down from Layer 4. Throughout Layer 5, the soil matrix remained reasonably consistent, with some lightening in colour as excavation progressed. This change in colour became distinct after the third $100 \mathrm{~mm}$ spit was removed, with the western side of the unit visibly darker than the eastern side. This was the first indication of an ancient sloping ground surface that became more apparent in Layer 6, interpreted as the slope down into a swale at the rear of a beach dune (see Figure 4).

Decorated and plain ceramic fragments were found throughout the layer, along with obsidian flakes and an obsidian core. Of particular note were eleven very similar, robust, and un-abraded decorated Lapita fragments in squares L8, L9, O9 and N9. These appeared to be in a primary deposit (due to their lack of surface abrasion) and stratigraphically consistent (they were found in two consecutive $100 \mathrm{~mm}$ spits during excavation, both within Layer 5).

Three burials were excavated from Layer 5 in 2008 (Burials 8, 9, 11), and two burials in 2009 (Burial 10 and 13) (see Figure 11 below). Burial 10 was found in 2008 but only partly excavated that year because it extended in to the baulk, and its recovery was completed in 2009.

\section{Layer 6 (Zone C2 lower)}

Layer 6 was a brown sandy soil, varying considerably in thickness from $300 \mathrm{~mm}$ to $800 \mathrm{~mm}$. The boundary between Layers 5 and 6 was not as distinct as higher boundaries, but the differentiation between the two layers was based on three observations. Firstly, in the sections there was an identifiable change in the matrix to a brown sand. Secondly, as mentioned above, a change from a relatively flat cultural surface to a sloping surface (dipping into a swale at the back of the beach ridge) could be identified. Thirdly, Layer 6 was characterised by two (possibly three) very distinct stone alignments running NE-SW (Figure 9), which also appear to be associated with evidence of industrial activity (stone tools, discussed below).

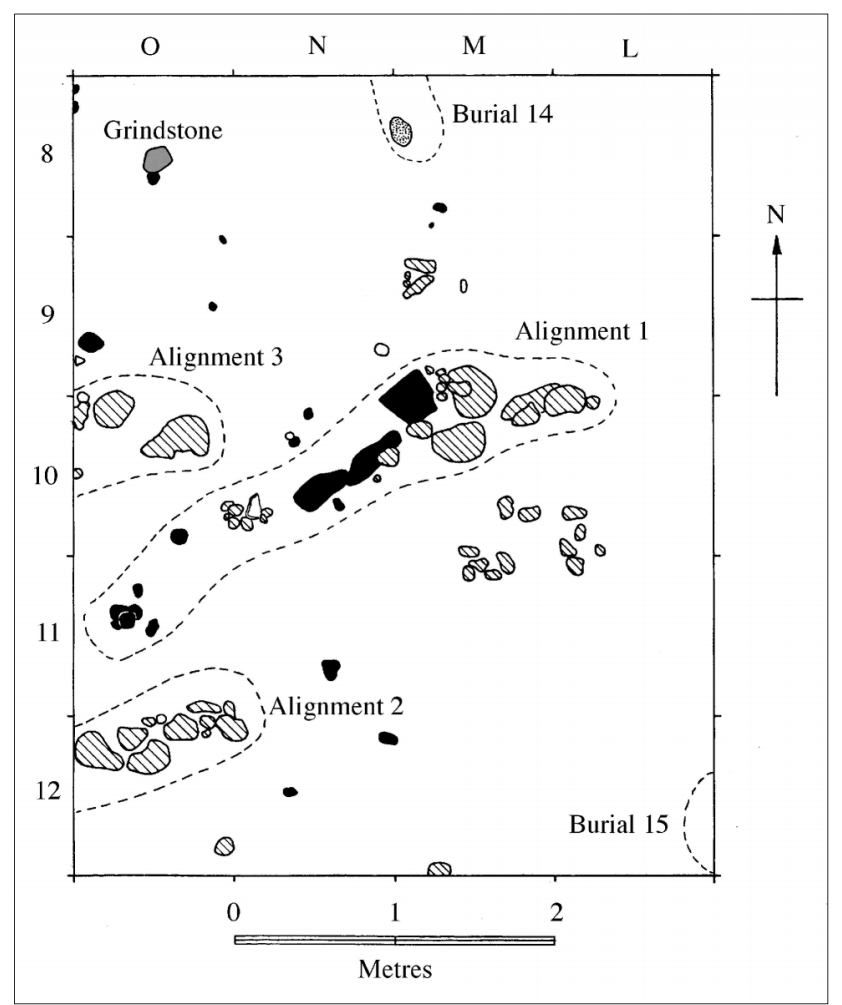

Figure 9: Stone alignments found in 2009. 
The longest stone alignment (Alignment 1) was found on the surface of Layer 6, and ran NE-SW a distance of 3.4 metres. It consisted of a mix of coral limestone and volcanic rocks, with the limestone clustered at the NE end. It was perpendicular to an alignment excavated by Anson \& Green in 1985 (see Anson et al. 2005: Figure $5 \mathrm{~b}$ ), and may be related to that feature. A second stone alignment (Alignment 2) was exposed after the first $100 \mathrm{~mm}$ spit of Layer 6 was excavated. This second alignment consisted entirely of limestone coral rocks. It was closer to E-W than Alignment 1, and was both actually and stratigraphically deeper than Alignment 1 . The third possible alignment (Alignment 3 ) was at the same stratigraphic level as Alignment 2. This alignment consisted of only a few limestone coral rocks, and may have extended towards the west, into the unexcavated baulk. Not enough of this feature was exposed to confirm its identification.

Three very distinct pits with blackened or heatmodified sands, which were interpreted as hearths or ovens, were cut from Layer 6 down into Layer 7. The deepest of these was $500 \mathrm{~mm}$ deep, dug well into the sterile sands below most of the Layer 7 features.

A grindstone and a pumice file or abrader were found in the NW quadrant of the unit. While industrial items (such as a hammer stone and another pumice file) were also found in Layer 5, the presence of the larger, heavier grindstone at this level strongly suggests that industrial activity was occurring here at the same time as the stone alignments were constructed, although a note of caution must be raised, as this NW corner was the location of the deep pit feature that was first noted in Layer 4, and therefore it is possible that items in this area were related to this pit feature.

Two burials were found in Layer 6 (Burials 14 and 15, see Figure 11). Burial 14 was found entirely within Layer 6 but extended into the north baulk of the unit. Burial 15 was mostly within the 1985 excavation unit, but was below the base of that excavation. It was cut down into Layer 7 from the lower part of Layer 6.

\section{Layer 7 (Zone D)}

Layer 7 consisted of light white/yellow beach sand and coral that had previously been interpreted as sterile. Anson et al. (2005) did note pits and postholes cut down into Zone D (Layer 7) from Zone C2 (Layer 6), but in 2009 pits and features cut within Layer 7 were identified. The Layer 6/Layer 7 interface was visible as a distinct change in colour from the dark Layer 6 sandy matrix to the much lighter Layer 7. The slope down into the ancient swale to the west also became more pronounced. Unfortunately Layer 7 extended into the tidal water table, and it was not possible to excavate it fully.

The features cut within Layer 7 were several large pits ( 0.5 to $0.7 \mathrm{~m}$ across) and a number of possible post holes (Figure 10). In common with Layer 6 it was found that deeper features were found on the west side of the 2009 SAC unit, again supporting the argument that this was the edge of a swale at the back of the beach ridge.

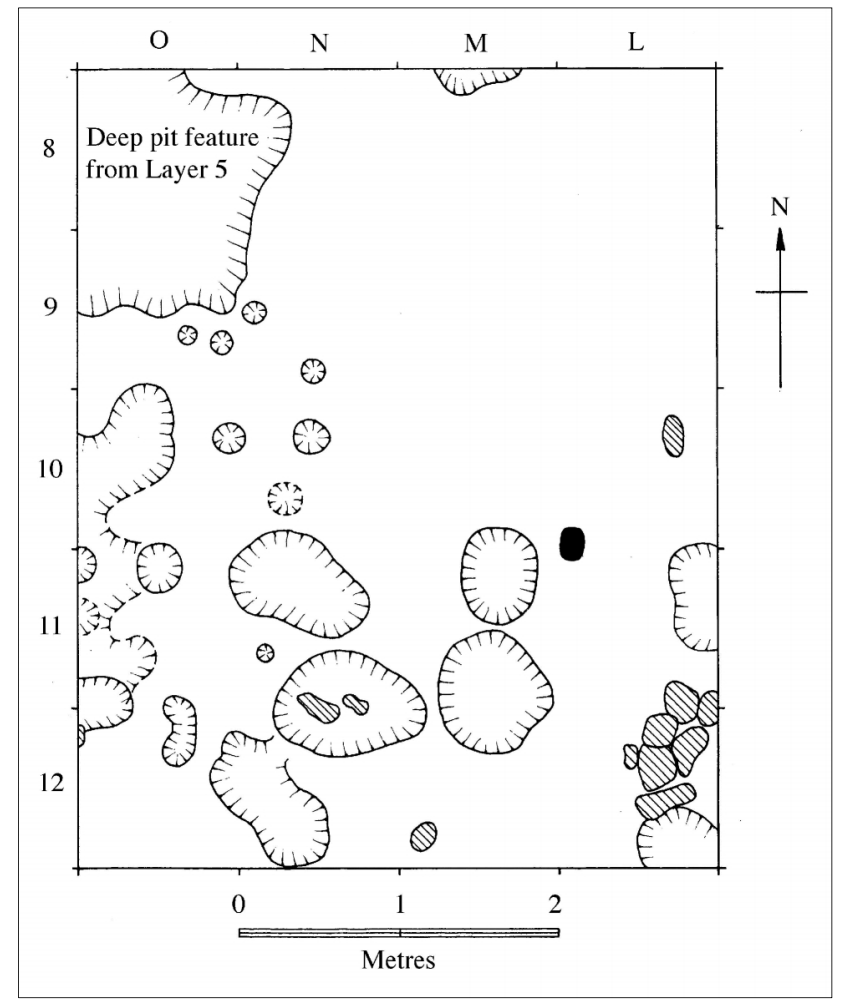

Figure 10: Features in Layer 7.

A large pit in the NW corner of the unit (squares O8, O9) continued down from the higher layers (as discussed above), but the base of it could not be fully investigated because of the inflow of ground water.

There was also a cluster of limestone coral rocks (200 $\mathrm{mm}$ to $400 \mathrm{~mm}$ across) in the SE corner of the unit (square L12). As these were right on the edge of the baulk it is not known whether they were part of a longer alignment. Again, this feature could not be fully investigated as it was below the tidal ground water table.

\section{The Deep Pit Feature, NW Corner}

Across most of the unit (and in previous SAC excavations) the boundaries between Layers 3 and 4 (Zones $\mathrm{B}$ and $\mathrm{C} 1$ ) and Layers 4 and 5 (Zones $\mathrm{C} 1$ and $\mathrm{C} 2$ ) were quite distinct and unequivocal. But mention has been made above of a deep pit feature that was found in the north west corner of the 2009 SAC excavation, and extended in some form down from Layer 4 to Layer 7. While not always clear during spit excavation, this pit feature was quite obvious in the north and west sections (Figures 4 \& 5). It was completely capped by the Rabaul ashfall (Layer 3 ), and so is not intrusive from above this level.

The location of this feature was on the edge of the ancient swale identified across the western half of the 2009 SAC unit. It appears to have been a large pit on the back of the beach ridge, and it may have been periodically cleared out, as some lensing was observed in its sides at lower levels. It was possibly a well, although the tidal water flowing in the sands is likely to have been brackish. The level from which it was originally cut is not clear, as 
the possible periodic cleaning out has complicated the stratigraphic context. It was possibly cut down from Layer 5, although some remnant of the pit may have persisted through Layer 4, which was partially, but not wholly, intact above the pit. An alternative explanation for the Layer 4 and 5 expression of the pit is that it was originally capped by these layers but the disturbance was caused by bioturbation from crabs somehow attracted to the different soil conditions caused by the buried pit in Layers 6 and 7. Specht has recorded modern material being as much as $2.2 \mathrm{~m}$ deep at Watom area SAD due to crab burrowing (Specht 2003: 133), and the area of concern here is between $1.2 \mathrm{~m}$ and $1.6 \mathrm{~m}$ below the surface.

Whatever the explanation for this feature, it is limited in area and does not otherwise alter the interpretation of the overall site. It does, however, complicate the stratigraphic context of cultural material found in Layers 4 to 7 from the NW corner of the 2009 unit.

\section{THE BURIALS}

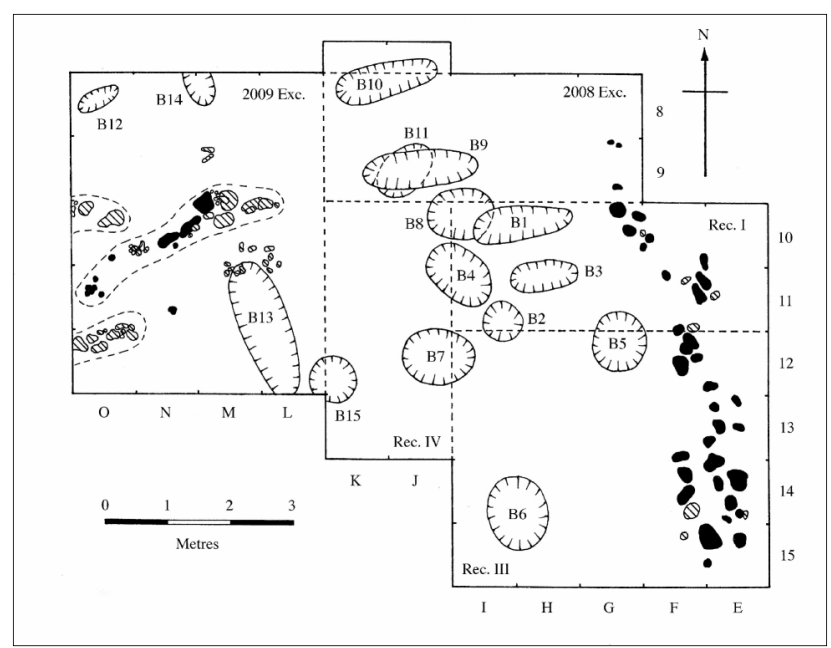

Figure 11: Distribution of all burials and main stone alignments in the 1985, 2008 and 2009 excavations.

Eight burials were completely or partially excavated from SAC in the 2008/09 excavations. Burial numbers were carried on from the earlier excavations of Anson and Green, who recovered human remains from eight burial features. Burial 8 was only partially recovered in 1985, and the 2008 excavation commenced with the recovery of the remainder of this burial. The location of all burials are shown in Figure 11. Burial 12 was that of a child buried above the Layer 2 ash. This means that at the SAC locality there is now a total of 14 identified pre-ashfall inhumations containing the remains of at least 19 individuals. All of these burials were within Layers 5 or 6 (Zone C2), and were capped by Layer 4 (Zone C1). The inclusion of human bone fragments in the general spits and not clearly associated with burials (non-burial human bone) in the Layer 4 material is possibly due to the disturbance of burials by gardening activity. The non-burial human bone consisted mainly of loose teeth and small cranial and vertebral fragments. The possibility of these fragments being associated with disturbed burials was checked in the field and assigned to the burial where possible.

\section{Burial 8}

Burial 8 was partly excavated during the 1985 SAC excavation, but it extended into the north baulk and could not be fully recovered. The remainder of the burial was excavated in 2008 (see Figure 12) and consisted of a partial cranium (including parts of the face), near complete mandible, left and right scapula and clavicle, near complete left humerus (head and neck were missing), rib and cervical fragments, lower limb fragments and some foot bones. The mandible was placed under the partial cranium but was not in direct articulation. The humerus was vertical, suggesting a seated position but the lack of articulation of other remains makes the determination of body position impossible. The lower limb fragments were gracile while the cranial and upper limb remains were robust suggesting at least two adult individuals were interred here. The morphology of the cranial remains is strongly suggestive of a male. The burial was within Layer 5 (Zone C2).

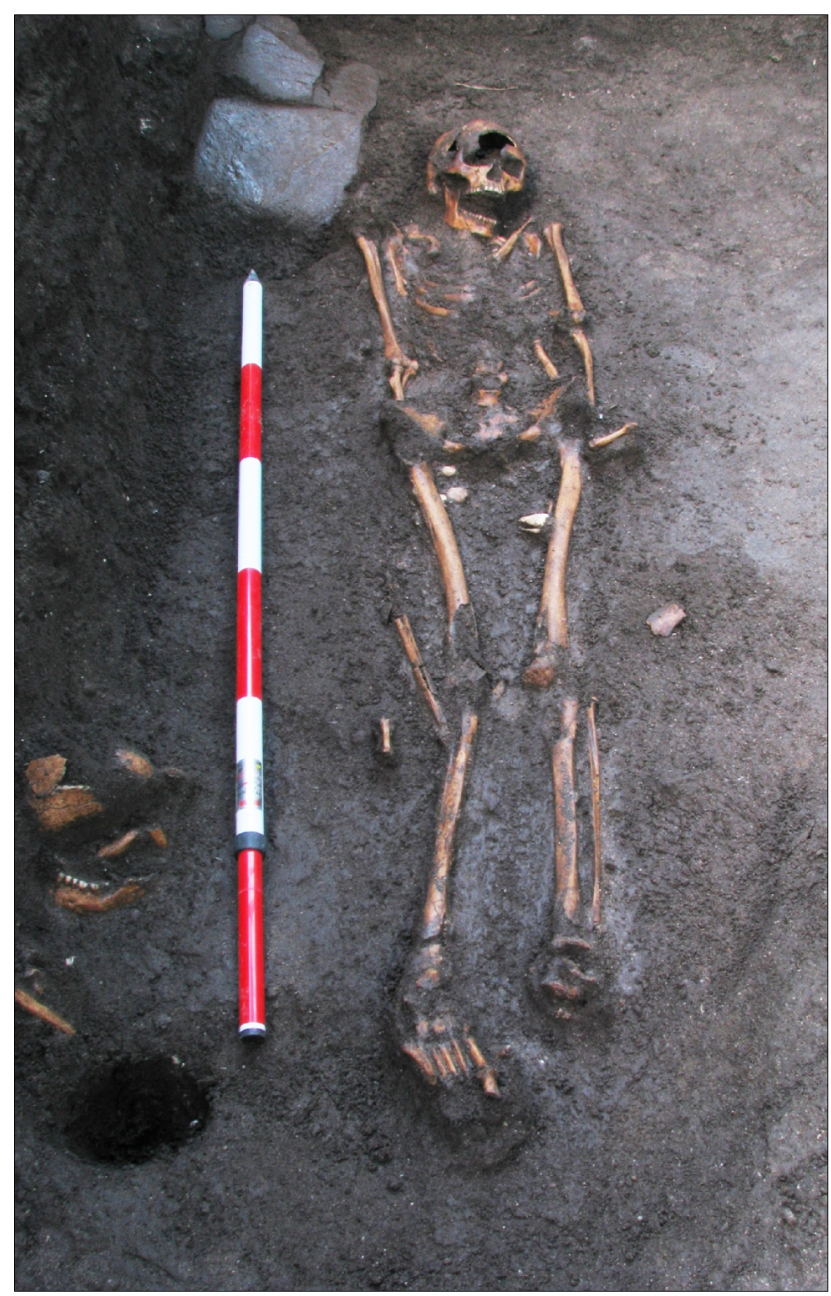

Figure 12: Burial 9, the well-preserved skeleton of an adult female. Burial 8 is exposed in the base of the baulk to the left of the feet of Burial 9. 


\section{Burial 9}

Burial 9 was excavated in 2008. The adult female burial (Figure 12) was supine, with the head to the west. The skeleton was articulated and in good physical condition, although the left foot was missing. The burial was within Layer 5 (Zone C2), and lay almost immediately over the disturbed Burial 11.

\section{Burial 10}

Burial 10 was partially excavated and lifted in 2008, with the remainder excavated in 2009. The adult burial female was interred on its right side, with the legs slightly flexed and head to the west. The skeleton was articulated and undisturbed, although being excavated over two seasons (and reburied between) led to some damage.

The grave was cut from Layer 5 (Zone C2) into Layer 6 , the identifiable (i.e. visible) grave being $160 \mathrm{~mm}$ deep (measured from observed highest to lowest points of grave cut), and the base of the grave cut was $260 \mathrm{~mm}$ below the top of Layer 5 . The highest visible indication of the grave cut was therefore $100 \mathrm{~mm}$ below the surface of Layer 5.

\section{Burial 11}

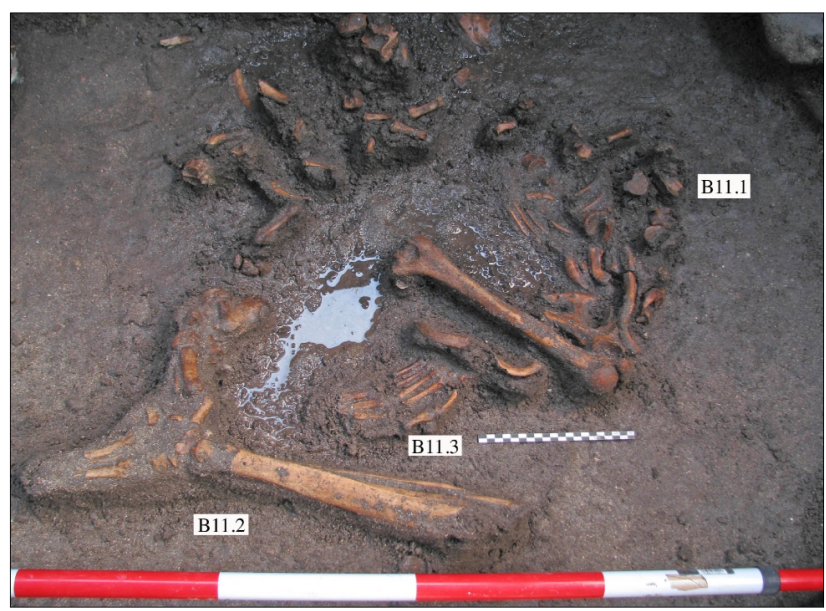

Figure 13: Burial 11, with groups of partially articulated bones from three identified individuals labelled.

Burial 11 was found immediately below Burial 9, and had been disturbed (probably by the interment of Burial 9). The burial (Figure 13) consisted of the articulated remains of three partial individuals and the disturbed hand and foot bones of at least two other inviduals, one of which was a young child. The grave cut could not be identified during excavation but based on the horizontal and vertical extent and depth of the human bones all of the remains were probably contained within a roughly circular pit. The majority of the remains belong to a single individual (B11.1) which consisted of an articulated left shoulder, arm and upper thorax of a young adult male. The hands and pelvis of this person were also found in an anatomically logical position. The upper neck vertebrae (cervical
1 and 2) were present but there were no cranial fragments or teeth found. The presence of the upper neck vertebrae may suggest the skull had been removed sometime after burial, but before the decomposition of the ligaments holding the teeth into the jaws. This individual was buried supine with head oriented to the northwest. It is unclear how the bodies of the other two partial individuals were reduced, whether by bone removal or from intercutting subsequent burial activity. However, the proximal tibia and fibula of 11.2 have been cut and broken below the joint which may support the interpretation of intercutting rather than bone removal from a primary burial.

Stratigraphically the relationship between Burials 9 and 11 was quite clear, with Burial 9 overlying Burial 11. Burial 11 was dug within Layer 5 and may also include mixing with Burial 8 or even a continuation of the Burial 8 mortuary complex.

\section{Burial 12}

Burial 12 was found above the Rabaul volcanic ash (Layer 3), and is therefore not part of the pre-ashfall burial assemblage. The burial was that of a child placed in a pit that was either too small for the body or had a distinct curve to the base, as the head and lower legs were raised up, and both had been partially cut away by postinterment activity. The body was supine, with the head towards to west. The burial was cut from within Layer 1 (Zone A), being dug just into the Layer 2 (Zone B1) reworked ash. No grave cut was observed prior to the discovery of the skeleton.

\section{Burial 13}

Burial 13 was an adult burial. The body had been badly disturbed but the right arm and left forearm were largely intact and in anatomical position suggesting a supine position with the head oriented to the north. The remnants of articulated but fragmented left ribs and pelvic fragments in expected anatomical position further support this interpretation. The burial was entirely within Layer 5 (Zone C2 upper). Several stones standing on edge marked the side of the original grave cut, which extended down from the surface of Layer 5. As the grave cut extended only $140 \mathrm{~mm}$ below this surface, it is likely that the body had been interred when the ground surface was higher than the present surface of Layer 5, and that this surface was later truncated to some degree by Layer 4 activity. The burial fill was distinctively Layer 5 material, indicating that the burials were cut from within this layer, and not from Layer 4.

\section{Burial 14}

Burial 14 was an adult burial that extended into the north baulk of the SAC excavation. The partial cranium, shoulders and upper thorax were visible in the excavation unit, and while the extremities of the humerii were damaged the burial retained a logical anatomical position (Figure 14). The thoracic vertebrae were in articulation, with the vertebral bodies facing superiorly, indicating the body 
was buried in a supine and extended position with the head oriented to the south.

The burial was within Layer 6 (Zone C2 lower). Where the burial was found this layer was quite thick (up to $500 \mathrm{~mm}$ ) due to the ancient ground surface falling to the west into the ancient swale. The burial was cut from within Layer 6, and the bottom of the grave cut was close to the Layer 6/Layer 7 interface. The grave cut itself was not well defined, and no top to the cut was identified, but the Layer 5/6 interface above the burial was distinct and unbroken.

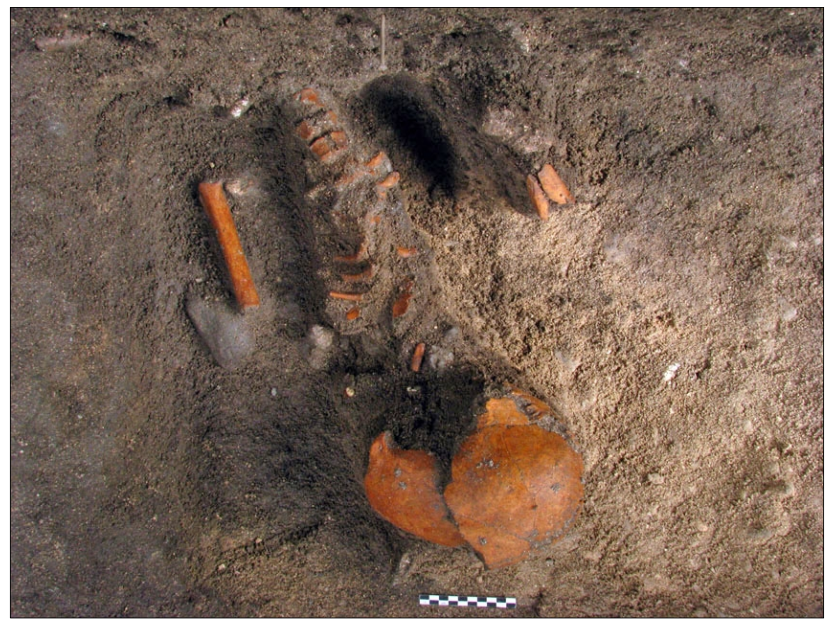

Figure 14: Burial 14, showing the incomplete but anatomically consistent upper body projecting from the north baulk of the SAC excavation.

\section{Burial 15}

Burial 15 was an adult male in a seated burial position. The body was complete and undisturbed (Figure 15) in a circular (or slightly oval) pit grave that was 1.5 to $1.7 \mathrm{~m}$ in diameter. A worked bivalve shell had been placed under the right elbow. Upon reconstruction of the skeleton in the laboratory the skull was found to be artificially deformed with a partially healed trepanation on the frontal bone. A full analysis of the life and death of this individual will be presented in a forthcoming publication.

The exact stratigraphic location of the top of the grave cut was difficult to determine, as the overlying material had been removed by the 1985 excavation. As the burial had not been observed at that date, it is most likely that it was cut from lower Layer 6 (lower C2) into Layer 7. This means that it was cut from well within Zone $\mathrm{C} 2$ (Layers 5 $\& 6)$. The top of the identified grave cut was $280 \mathrm{~mm}$ below the top of Layer 6. Burials 14 and 15 appeared to be at similar stratigraphic levels. Burial 15 was dug into clean Layer 7 sands, while Burial 14 was entirely within Layer 6 (which was thicker at its location), but the level from which both were cut appears to have been similar as in both cases Layer 5 was intact over the grave cut.

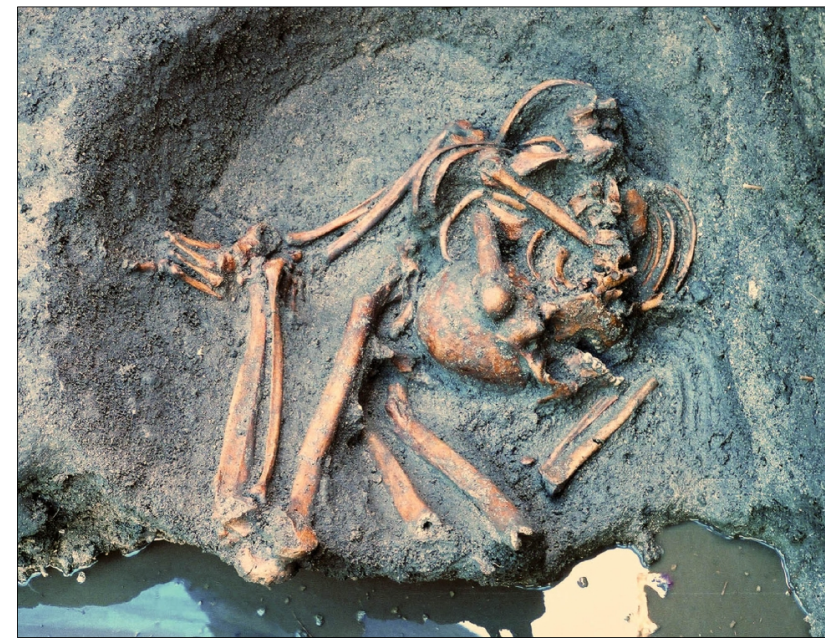

Figure 15: Burial 15, showing the well-preserved skeleton and the tidal water inflow into the excavation unit.

Table 2: Summary of burials from SAC (1985-2009).

\begin{tabular}{|c|c|c|c|}
\hline $\begin{array}{l}\text { Burial } \\
\text { No. }\end{array}$ & Age & $\operatorname{Sex}(1)$ & $\begin{array}{l}\text { Burial type and position } \\
\text { (2) }\end{array}$ \\
\hline 1 & 30 years & Female & $\begin{array}{l}\text { Supine, skull removed, } \\
\text { head to west. }\end{array}$ \\
\hline 2 & $18-20$ years & Female & $\begin{array}{l}\text { Unknown due to disturb- } \\
\text { ance. }\end{array}$ \\
\hline 3 & $30-40$ years & Male & $\begin{array}{l}\text { Supine with lower limbs } \\
\text { flexed, in oval pit. Head to } \\
\text { west. }\end{array}$ \\
\hline 4 & $23-39$ years & Male & $\begin{array}{l}\text { Skull removed. Supine with } \\
\text { limbs flexed in oval pit. } \\
\text { Shoulders to the west. }\end{array}$ \\
\hline 5 & 30 years & Male & $\begin{array}{l}\text { Unknown due to disturb- } \\
\text { ance. }\end{array}$ \\
\hline 6 & $30-35$ years & Male & Seated? in oval pit. \\
\hline 7 & Adult & Male? & $\begin{array}{l}\text { Unknown due to disturb- } \\
\text { ance. }\end{array}$ \\
\hline 8 & $20-30$ years $(3)$ & Male & $\begin{array}{l}\text { Pit feature with bones of at } \\
\text { least two people. }\end{array}$ \\
\hline 9 & $30-39$ years & Female & Supine, head to west. \\
\hline 10 & $20-29$ & Female & $\begin{array}{l}\text { Supine, lower limbs flexed } \\
\text { to right, head to west. }\end{array}$ \\
\hline 11 & $\begin{array}{l}\text { Multiple individu- } \\
\text { als (at least } 4 \\
\text { adults and one } \\
\text { young child) }\end{array}$ & & $\begin{array}{l}\text { Disturbed, possible pit } \\
\text { feature with the articulated } \\
\text { bones of two partial skele- } \\
\text { tons and the distrubed } \\
\text { remains of at least two } \\
\text { others. B11.1 had head to } \\
\text { northwest. }\end{array}$ \\
\hline 12 & 9 years & & Tolai period. Head to north. \\
\hline 13 & Adult & & $\begin{array}{l}\text { Disturbed, supine, head to } \\
\text { north. }\end{array}$ \\
\hline 14 & Adult & Male & $\begin{array}{l}\text { Disturbed, supine, lower } \\
\text { limbs in baulk, head to } \\
\text { south. }\end{array}$ \\
\hline 15 & $18-20$ years & Male & $\begin{array}{l}\text { Seated in round pit, head } \\
\text { to east. }\end{array}$ \\
\hline
\end{tabular}

(1) Age and sex estimates based on methods contained in Buikstra and Ubelaker (1994). (2) The burial positions, oritentations of burials 1-7 and the interpretation of head removal in burial 1 are from Green et al. (1989) and for burials 1-3 are based on Specht (1968) and synthesised by Green et al. (1989). The burial type and position descriptions of burials 8-15 are those of the current authors. (3) This age and sex estimation is based on the majority of the remains. At least one other more gracile adult was interred in this feature. 


\section{MORTUARY PRACTICES AT SAC}

Based on the 1985 and earlier excavations Green et al. (1989) described two modes of inhumation at SAC; supine extended burial without the cranium with no discernible grave cut (Burial 1), and supine flexed burials in an oval or round pit with crania (Burials 3 and 4) although the Burial 4 cranium was probably disturbed in antiquity. Burial 6 was "lying in a seated position flexed position on its back" (Green et al. 1989: 219). The remaining four burials (Burials 2, 5, 7 and 8) were incomplete and mostly disarticulated, and were interpreted as primary inhumations disturbed by later gardening activity or secondary burials. The orientation of the heads of the burials showed a preferred mode of placement with the head to the west in Burials 1, 3, 4 and 7.

The inhumations excavated in 2008 and 2009 generally followed this pattern of supine burial, with limbs extended (Burial 9) or semi-flexed (Burial 10), although there were some notable differences. Burial 15 was seated and complete, and Burial 11 (with up to five individuals represented) does not fit into either of the categories described by Green (1989) as the remains of some of the individuals were articulated and not all were disturbed as observed in burials 2, 5, 7 and 8. The discovery of the new burials from the SAC site also offers some opportunity to consider sex differences in burial treatment at the site. Of the four females from the cemetery, three (Burials 1, 9 and 10) were buried supine with limbs extended or semi-flexed and with their heads oriented to the west. The remaining female, Burial 2, was one of the disturbed burials so could not be assessed for burial position. These three females are also aligned on a NW- SE oriented 'line' which may indicate a structure to the burial site use. The male inhumations on the other hand were all buried 'flexed' or seated in pit features with their heads in variable orientations. The patterns of disturbance of some of the burials in the earlier and more recent excavations are probably the result of a number of effects, including intensive mortuary activity, later gardening activity and animal burrowing.

\section{BIOLOGICAL AFFINITIES, MOBILITY AND DIET OF THE SAC INDIVIDUALS}

When reporting on the burials recovered in 1985, Houghton (1989) described the health of the Lapita-era Watom residents as good with little or no evidence of chronic infectious disease or ill-health during childhood. The health and disease of the new burials in the wider Lapita context will be reported in a forthcoming publication. However, isotope and morphological and metric data from the 2008-09 burials have been reported in a series of publications (Shaw et al. 2010; Pietrusewsky et al. 2014; Kinaston et al. 2015; Kinaston et al. 2016).

Burials 1 to 8 were previously described by Pietrusewsky (1989) and Houghton (1989) as tall, with 'rocker jaws' and shovel shaped incisors as evidence of morphological similarities to Polynesians but different to all other Pacific Island populations as they have small teeth, gracile limb bones and short and broad mandibles.
Multivariate analysis of mandibular metrics by Pietrusewsky (1989) supported his assertion that the Watom skeletons were dissimilar to modern Polynesians, as measured by these variables. Metric analyses of the crania were not possible due to the fragmentation and postmortem damage of the material. Recently, Pietrusewsky et al (2014) analysed the mandibles of male Burials 3, 6, 8 and 15 in a biodistance study and concluded that these individuals were morphologically most similar to eastern Melanesian groups. As found in his earlier biodistance craniometric analyses, Pietrusewsky argued these data continue to support an ancestral Polynesian homeland from the Wallacea region rather than from within Melanesia.

The migration and mobility patterns of people and pigs from Watom was carried out by Shaw et al. (2010) using strontium isotope ratios $\left({ }^{87} \mathrm{Sr} /{ }^{86} \mathrm{Sr}\right)$, oxygen isotope values $\left(\delta^{18} \mathrm{O}\right)$, and $\mathrm{Ba} / \mathrm{Sr}$ trace element data from tooth enamel. One human (Burial 9) and several pigs were found be of non-local origin suggesting a greater level of mobility and interaction during the late Lapita phase than had been previously assumed based on material culture analyses. Most recently Kinaston et al. (2015) analysed the stable isotope values $\left(\delta^{13} \mathrm{C}\right.$ and $\left.\delta^{15} \mathrm{~N}\right)$ from the bone collagen of human individuals $(n=8)$ and faunal remains, including domesticated pig (Sus scrofa), to assess human diet and methods of animal husbandry at the site. The protein diet of the humans consisted of marine species from the inshore environment and some deep-water species (most likely marine turtle), in addition to terrestrial foods, probably pig and native animals such as fruit bat, cuscus, and bandicoot. The females $(n=4)$ displayed more variable $\delta^{13} \mathrm{C}$ and $\delta^{15} \mathrm{~N}$ values compared with the males $(n=4)$, which may be associated with the movement of adult females to the island, further supporting the findings of Shaw et al. (2010).

The stable isotope analysis of the pigs indicated that there were few differences between the diets of pigs from the Lapita and post-Lapita layers at SAC, suggesting that the method of pig husbandry was similar between these two periods and was likely relatively free-range, as it is on the island today (Kinaston et al. 2015). The oral health and stable isotope evidence of diet in the Watom people and pigs has also been analysed in a comparative study of Watom and other Lapita human and faunal assemblages, specifically those from Vanuatu (Teouma and Uripiv) to assess differences in diet and methods of animal husbandry between Near and Remote Oceania and Early and Late Lapita populations (Kinaston et al. 2016). It was found that the timing of settlement on each island had large effects on the type of subsistence practiced by each community. The earliest settlers of Teouma engaged in a more broad-spectrum hunting and foraging method of subsistence. The later Lapita communities, including those on Watom, had a heavier reliance on horticultural and aboricultural foods. The methods of pig husbandry were most influenced by regional differences in island ecology and island size. The pigs on the larger islands, such as Watom, appeared to be raised by a free-range method in both the 
Lapita and post-Lapita periods because there was adequate land for them to forage on (Kinaston et al. 2016).

\section{MATERIAL CULTURE FROM SAC}

The material culture recovered from SAC consisted principally of ceramics, lithic material and worked shell debitage, most of which was recovered from layers 4, 5 and 6. The entire assemblage is summarised here, although more detailed analyses have been and will be carried out.

\section{Ceramics}

A large number of pottery sherds were discovered during the $2008-2009$ excavations $(2008$ NISP $=130,2009$ NISP $=438)$ (NISP $=$ number of individual specimens present, ie number of sherds), including Lapita dentatestamped pottery and pottery decorated with nailimpression and applied relief (Figure 16). Ceramic fragments were found throughout Layers $4,5 \& 6$ (zones $\mathrm{C} 1$ $\&$ C2), and were absent from Layers 1, 2, 3 and 7 (zones A, B D). The stratigraphic distribution of the ceramics at SAC in 1985, 2008 and 2009 is summarised in Table 3. This assemblage will be described in more detail in an upcoming paper by Anson, and only a brief overview is presented here.

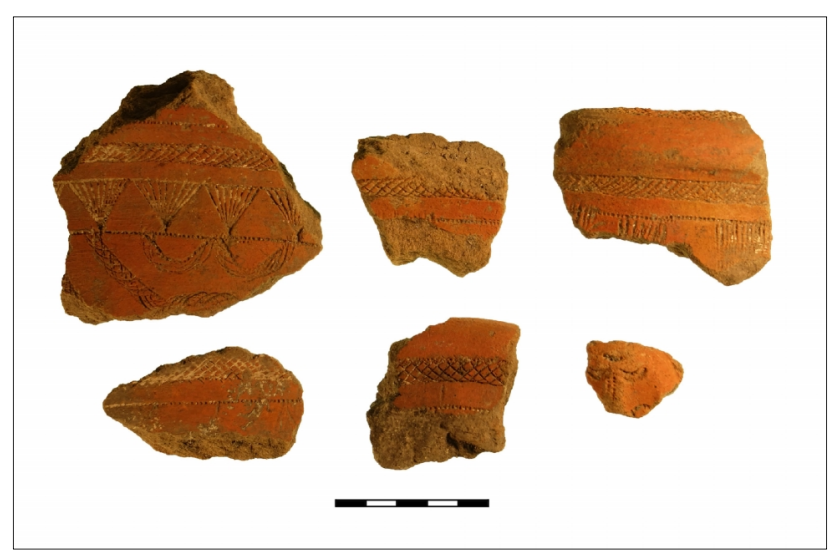

Figure 16: Six of the unworn Lapita ceramic fragments from Layer 5 (cat 20046, 20047, 20056, 20069, 20073, 20095). Scale $50 \mathrm{~mm}$.

The stratigraphic distribution of the increased sample of dentate-stamped and nail-impressed and applied relief pottery at SAC in 2008 and 2009 was consistent with that observed in 1985, namely that while the decorated Lapita pottery is found in Layers 4, 5 and 6 (zones C2 and C1), albeit in small numbers, pottery decorated with nail impression and applied relief does not appear until the the beginning of Layer 4 (zone $\mathrm{C} 1$ ). There was no nailimpressed and applied-relief pottery found in Layers 5 and 6 (zone C2) in 1985, 2008 or 2009.

Of note amongst the pottery finds unearthed by the 2009 excavations were eleven, crisply broken, unrolled sherds that were possibly from a single (ie $M N V=1$ ) $(\mathrm{MNV}=$ minimum number of vessels that can account for the sherds present) small diameter thick-walled pottery stand decorated with dentate stamp designs that include a possible stylised human face (Figure 16). These sherds were found within Spits 1 and 2 of Layer 5 scattered over an area of four square metres. Their spatial and stratigraphic distribution and unworn appearance suggests that they were found in primary context on an occupation surface, and this confirms Lapita occupation at this level. Another Lapita sherd that is of interest was decorated with a finely dentate-stamped motif (see Anson 1983: Table XII:120) which appears to be indicative of Far Western or Early Lapita pottery (Anson 1986: 157-165; Summerhayes 2010).

\section{Lithic Material}

The lithic material consisted of obsidian (flakes, cores and waste), stone adze fragments, two abraders/files, a grindstone and a hammerstone.

\section{Obsidian}

A total of 787 obsidian fragments were found in 2008 and 1447 in 2009 . Obsidian is particularly useful in the study of Lapita exchange networks, and studies have focussed on procurement, movement and utilisation. In 2008/09 obsidian was found in all of the cultural layers at SAC except for the Layer 2 ash and Layer 7. Samples from the 2008 and 2009 SAC excavations were analysed by James Slater (2008) and Yilin Chen (2012) respectively. Both used PIXE-PIGME analysis, and Chen also used PXRF analysis, to determine the source of the obsidian samples.

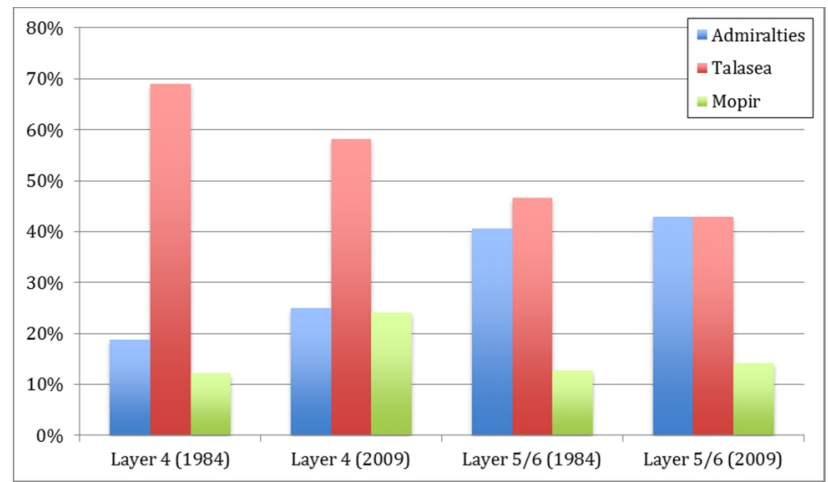

Figure 17: Obsidian source attributions per layer, based on Chen 2012

Slater examined a sample of 28 pieces of obsidian $(22$ from Layer 4/Zone $\mathrm{C} 1$ and 6 from Layers 5 \& 6/Zone C2), and found that West New Britain sources dominated, with a smaller amount of Admiralty Islands sourced material. In contrast to other studies of SAC obsidian he found that the proportion of Admiralty source did increase slightly through time, although this is likely to be the result of a small sample size. Chen used PIXE-PIGME analysis on a sample of 12 flakes taken from squares L11, 112 and N11, with 6 each from Layer 4 (Zones C1) and Layers 5/6 (Zone C2) from the 2009 excavation. 
Table 3: Stratigraphic relationships of pottery (NISP counts) from the 1985, 2008 and 2009 seasons at SAC.

\begin{tabular}{|c|c|c|c|c|c|c|c|}
\hline Layer & Year & Plain & Brushed & Dentate & Incised & Nail & Relief \\
\hline $4(\mathrm{C} 1)$ & 1985 & $495(94.3 \%)$ & $4(0.8 \%)$ & $17(3.2 \%)$ & $6(1.1 \%)$ & $3(0.6 \%)$ & 0 \\
\hline $4(\mathrm{C} 1)$ & 2008 & 73 (89\%) & $5(6.1 \%)$ & $1(1.2 \%)$ & 0 & $2(2.4 \%)$ & $1(1.2 \%)$ \\
\hline \multirow[t]{2}{*}{$4(\mathrm{C} 1)$} & 2009 & $236(88.4 \%)$ & $11(4.1 \%)$ & $16(6 \%)$ & $3(1.1 \%)$ & $1(0.4 \%)$ & \\
\hline & Total & $804(91.9 \%)$ & $20(2.3 \%)$ & $34(3.8 \%)$ & $9(1.0 \%)$ & $6(0.7 \%)$ & $1(0.1 \%)$ \\
\hline 5,6 (C2) & 1985 & $119(90.8 \%)$ & $2(1.5 \%)$ & $9(6.9 \%)$ & $1(0.8 \%)$ & 0 & 0 \\
\hline 5,6 (C2) & 2008 & $41(85.4 \%)$ & $4(8.3 \%)$ & $1(2.1 \%)$ & $2(4.1 \%)$ & 0 & 0 \\
\hline 5,6 (C2) & 2009 & $132(77 \%)$ & 17 (9.9\%) & $17(9.9 \%)$ & $4(2.3 \%)$ & 0 & $1(0.6 \%)$ \\
\hline & Total & $292(83 \%)$ & $23(6.6 \%)$ & $27(7.7 \%)$ & $7(2 \%)$ & 0 & $1(0.3 \%)$ \\
\hline
\end{tabular}

Fourteen elements were measured ( $\mathrm{Na}, \mathrm{Al}, \mathrm{Si}, \mathrm{K}, \mathrm{Ca}, \mathrm{Fe}$, F, Ti, Mn, Zn, Rb, Sr, Y, Zr) (Chen 2012: 89). High proportions of $\mathrm{F}(>1000 \mathrm{ppm})$ were used to differentiate Admiralty and West New Britain sources, while relatively low $\mathrm{F}, \mathrm{K}, \mathrm{Rb}, \mathrm{Zr}$ and high $\mathrm{Na}, \mathrm{Ca}$ and $\mathrm{Mn}$ concentrations were used to indicate Mopir obsidian (Chen 2012: 90). Nine ratios $(\mathrm{Al} / \mathrm{Na}, \mathrm{F} / \mathrm{Na}, \mathrm{K} / \mathrm{Fe}, \mathrm{Ca} / \mathrm{Fe}, \mathrm{Mn} / \mathrm{Fe}, \mathrm{Rb} / \mathrm{Fe}$, $\mathrm{Sr} / \mathrm{Fe}, \mathrm{Y} / \mathrm{Fe}, \mathrm{Zr} / \mathrm{Fe}$ ) were used to distinguish Melanesian sources from each other (Chen 2012: 90). Chen identified one flake from the Admiralty Islands, two from Mopir and nine from Talasea (Chen 2012: 92, Table 4.2). Chen then used PXRF analysis on a larger sample of 94 flakes from the same square (Figure 17), consisting of 80 from Layer 4 (Zone $\mathrm{C} 1$ ) and 14 from Layers 5 and 6 (Zone $\mathrm{C} 2$ ). Of these 25 were from the Admiralties, 16 from Mopir, 51 from Talasea and 2 were unassigned (Chen 2012: 106, Table 4.11). The results show a dominance of West New Britain obsidian (especially Talasea) at all times, together with an increase in use over time. The Admiralty Islands sources were always less important and decreased further over time (Chen 2012: 117). This is a similar result to the analysis of the 1985 excavation obsidian, which found that the sequence began with just a small dominance of Talasea (41\%) to Admiralty (41\%) obsidian in Layers 5 and 6 (Zone C2), but over time the proportion of the Talaseas source doubled (Anson et al. 2005: 21).

Chen and Slater also examined the technological use of the obsidian. Chen used a sample of 155 flakes from squares L11, L12 and N11, comprising all artefacts within those squares from Zone C (Layers 4, 5 and 6) (Chen 2012: 119-120). This material consisted of 8 cores, 68 flakes, 72 pieces of angular shatter and 7 pieces of chipping waste. She found that the amount of obsidian increased over time and the weights of cores decreased over time, suggesting a rising importation and intensity of reduction from the Lapita to the transition period (Chen 2012: 131, 151-152). Slater (2008: 97) came to similar conclusions regarding the smaller 2008 assemblage.

\section{Adzes, Abraders, Grinders, Hammerstones}

Twelve stone artefacts (other than obsidian) were found during the 2009 excavation. One of these, a stone adze fragment, was found in Layer 1, and all of the rest were found below the volcanic ash layers. These artefacts have yet to be analysed in detail, but a brief preliminary description is given here.

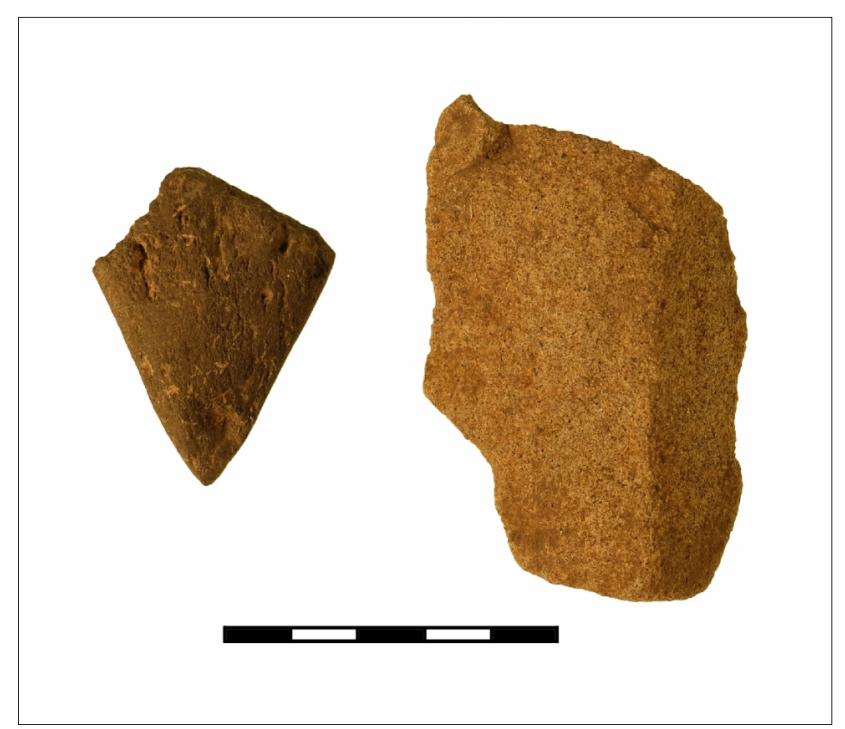

Figure 18: Stone file and grindstone from Layer 4 (cat 20009, 20041). Scale 50mm.

Layer 4 (Zone C1) contained two adze fragments, two files and a grindstone. The adze fragments were both small pieces of flaked stone with one polished surface. One was a core, with three or four flake scars, while the other was a flake. One file was diamond-shape in plan, 46 $\mathrm{mm}$ long and $24 \mathrm{~mm}$ thick (Figure 18). The other was rectangular in plan and oval in section and was broken short, the surviving section measuring $42 \mathrm{~mm}$ long and 34 
mm wide. The grindstone was made from sandstone in an irregular shape $75 \mathrm{~mm}$ long, and had one well-worn face.

Layer 5 (C2 upper) contained two adze fragments, a grindstone and a hammerstone. The adze fragments were both more intact than those from Layer 4, and both included part of the cutting edge. Both have a planilateral cross section, that Green \& Anson (1998: 59) considered to be typical of one form of Lapita adze type. One was a green colour, in common with other SAC adze fragments reported by Green, Anson and Specht (Green \& Anson 1988: 60-61). The hammerstone was $95 \mathrm{~mm}$ in length and $48 \mathrm{~mm}$ in diameter, and showed percussion damage in four places long its long axis, with a smaller amount of damage at its ends. This indicates that it was mainly used to apply a flatter wider blow rather than a sharp pointed blow.

Layer 6 contained a grindstone and a pumice file (Figure 19). The file was a similar shape to (but larger than) one file from Layer 4, as it was worn to a triangular blunt point at one end as a result of a hand-filing action. It measured $97 \mathrm{~mm}$ long and $86 \mathrm{~mm}$ wide. The grindstone (or quern) was a large squarish rock about $180 \mathrm{~mm}$ across and $75 \mathrm{~mm}$ thick, with two wide parallel grooves worn in its upper flattish surface. It was probably set firmly into the ground or a mount, and then used for sharpening or grinding objects. It therefore was used as a quern rather than a hand-held file.

The collection of hand tools suggests that industrial activity did occur throughout human occupation at the SAC site. The most robust tools were found in Layers 5 and 6, which are associated with the Lapita period and with the period of construction of stone alignments. However a note of caution must be raised, as the NW corner where several items (including the quern) were found was the location of the deep pit feature that was first noted in Layer 4, and therefore it is possible that items in this area were related to the use or backfilling of this feature.

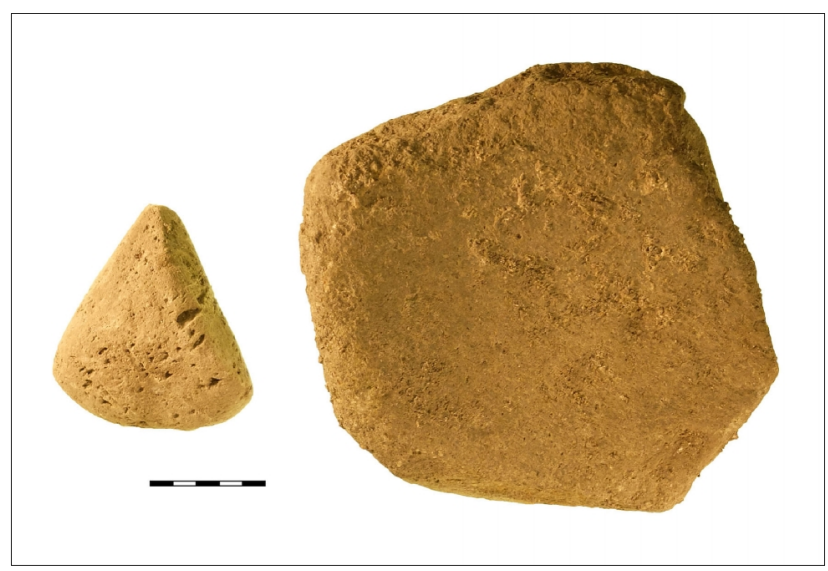

Figure 19: Pumice file and large grindstone/quern from Layer 6 (cat 20088, 20089). Scale 50mm.

\section{Shell Pendant}

A single fragment from a shell pendant was found with Burial 9 in 2008. This is illustrated in Figure 20. The pendant is a flat thin-walled turbo-like shell that has defoliated into two sections. It is presently held by the Otago Museum (loan number L2008.717).

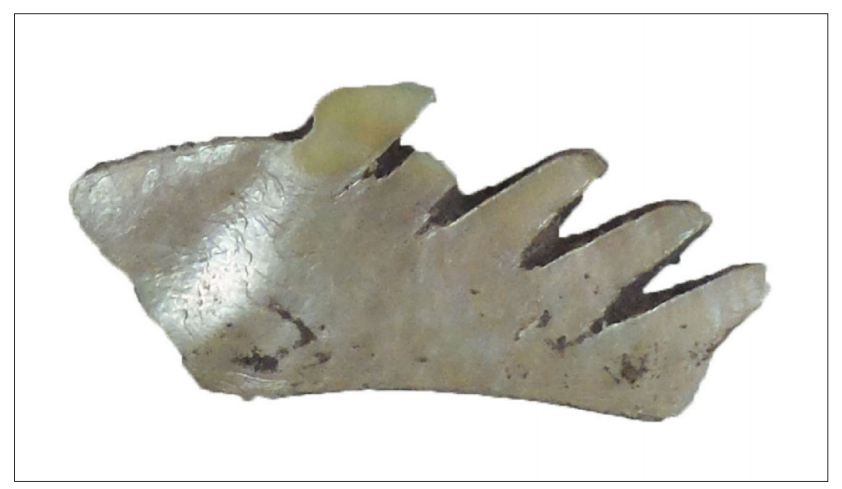

Figure 20: Shell pendant from Burial 9, presently on display in the Otago Museum.

\section{FAUNAL ANALYSIS}

The cultural layers at SAC all contained a low density of faunal material, particularly shell, as a general component of the soil matrix. The shell was highly fragmented and much was probably natural in origin. However, the context of shell deposition and the nature of fragmentation suggest that the bulk of the shell was deposited through anthropogenic processes, possibly due to industrial activities across the site (also indicated by the stone tools described above).

A total of 440 bags of faunal material (263 bags of shell, 177 bags of bone) was recovered from the coarse screens and transported to the Otago Archaeology Laboratories (OAL) at the University of Otago for further investigation. A hierarchical processing method was adopted in the laboratory. The midden sample was first sorted to primary class; shell, fish, mammal and bird. Within each class the sample was then sorted to sided anatomical unit and to the lowest possible taxonomic unit using standard archaeozoological processing methods (Reitz and Wing 2008). Taxonomic identifications were carried out using the Pacific faunal reference collections in the OAL and with reference to standard guides (e.g., Claassen 1998; Leach 2006, Reitz and Wing 2008, Serjeantson 2009). At all stages of processing the original provenance information as coded on the field bags was retained.

Vertebrate fauna were quantified using NISP, MNE and MNI (Grayson 1984, Reitz and Wing 2008). NISP is a natural count of specimens in the assemblage and is the basis for the generation of derived values ( $\mathrm{MNE}=$ minimum number of elements that can account for the specimens present, $\mathrm{MNI}=$ minimum number of individuals that can account for the specimens present) which are both subject to some bias. To reduce the problem of inflation with MNI (e.g., Grayson 1984) all derived values were calculated on a site-wide basis rather than at the excavation unit level. 
Table 5: Mammal bone identification

\begin{tabular}{|c|c|c|c|c|c|c|c|c|c|c|}
\hline Layer & & Rat & & & Pig & & & Human & & Unid \\
\hline & $M N I$ & NISP & $M N E$ & $M N I$ & $N / S P$ & $M N E$ & $M N I$ & NISP & $M N E$ & NISP \\
\hline 1 & 1 & 1 & 1 & 1 & 5 & 5 & 1 & 2 & 1 & 5 \\
\hline 4 & & & & 4 & 145 & 56 & & frags & & 58 \\
\hline 5 & & & & 2 & 91 & 44 & 1 & 1 & 1 & 30 \\
\hline 6 & & & & 1 & 7 & 8 & & & & 5 \\
\hline 7 & & & & 1 & 1 & 1 & & & & \\
\hline
\end{tabular}

\section{Shellfish}

Shell comprised a significant natural component of the sandy soil matrix in most layers, and was also present in all cultural layers, except Layer 2, as midden deposit. Bulk column samples were recovered and these all contained shell, but the bulk of shell recovered in the site was reburied due to transport constraints. The 1985 excavation was able to recover a larger and more comprehensive sample (while acknowledging similar practical constraints) and our field records suggest that the 2008 and 2009 excavation results are consistent with the earlier findings. We rely on those earier results to provide an overview of the shellfish component of the midden (see Green \& Anson 1998: 53-59, especially Table 4).

\section{Mammal}

A total of 353 fragments of mammal bone were recovered from the SAC excavations (Table 5). The sample was fragmented and the NISP to MNI ratio is low in all levels. Pig dominated throughout the sequence. As outlined above, human bone fragments probably represent burials that have been disturbed by gardening activity that were not identified in the initial field sorting of bone excavated from spits. Most of the human bone fragments from the Lapita layers were sorted from faunal remains in the field. An MNI has not been calculated for these small human fragments. As discussed above, analysis of stable isotope ratios in pig bones by Kinaston et al. (2015) suggests pig husbandry on Watom Island was relatively free-range throughout the Lapita and post-Lapita periods.

Fish

The fish bone assemblage from SAC was surprisingly small for a Pacific assemblage with only 144 specimens (NISP) (Table 6). The most common fish was Scaridae or parrotfish which is a reef browser and can be caught using a range of generalised fishing methods especially netting as it does not normally take a baited hook. The Layer 4 assemblage is dominated by small coral reef taxa (with the exception of the elasmobranches) and these are normally caught on hooks or with nets. The Layer 5 assemblage is somewhat different in that it includes two pelagic predators that are more commonly caught on hooks and lures. Carangidae or trevally commonly patrol the reef faces feeding on smaller schooling fish and are often caught on lures or baited lines within a few hundred metres of the reef, or in lagoons. Scombridae include the tuna and bonito and these schooling fish are more usually taken offshore on lures.

Table 6: Fish bone identification

\begin{tabular}{|c|c|c|c|c|}
\hline Layer & Taxa & NISP & MNE & MNI \\
\hline 1 & Unidentified & 2 & 2 & 1 \\
\hline \multirow[t]{8}{*}{4} & Acanthuridae & 2 & 2 & 1 \\
\hline & Balistidae & 1 & 1 & 1 \\
\hline & Labridae & 4 & 4 & 3 \\
\hline & Monotaxis grandoculis & 9 & 8 & 2 \\
\hline & Scaridae & 19 & 18 & 6 \\
\hline & Shark/ray & 1 & 1 & 1 \\
\hline & Sting ray sp. & 1 & 1 & 1 \\
\hline & Unidentified & 35 & & \\
\hline \multirow[t]{11}{*}{5} & Acanthuridae & 1 & 1 & 1 \\
\hline & Balistidae & 1 & 1 & 1 \\
\hline & Carangidae & 3 & 1 & 1 \\
\hline & Labridae & 1 & 1 & 1 \\
\hline & Lutjanidae & 2 & 1 & 1 \\
\hline & Monotaxis grandoculis & 1 & 1 & 1 \\
\hline & Scaridae & 9 & 8 & 3 \\
\hline & Scombridae & 1 & 1 & 1 \\
\hline & Serranidae & 3 & 3 & 2 \\
\hline & Shark/ray & 2 & 2 & 1 \\
\hline & Unidentified & 40 & & \\
\hline \multirow[t]{2}{*}{6} & Scaridae & 1 & 1 & 1 \\
\hline & Unidentified & 4 & & \\
\hline 7 & Scaridae & 1 & 1 & 1 \\
\hline
\end{tabular}

The previous fish bone analysis from SAC reported in Green and Anson (1998:52-53) shows strong agreement with these more recent findings. In their $\mathrm{C} 1$ Zone (equivalent to Layer 4) the dominant two taxa representing 74\% of the assemblage were Scaridae and Monotaxis grandoculis. These were also the two top ranked taka by MNI in this assemblage representing $53 \%$ of the sample. The 
conclusion drawn by Green and Anson was that the SAC assemblage represented a typical Lapita reef edge fishing strategy (e.g., Butler 1988). This is supported by the results reported here.

\section{Reptiles}

A total of 48 fragments of marine turtle remains were recovered this was mainly carapace or plastrom but did include a few vertebral fragments. The distribution of marine turtle remains in the site is shown in Table 7.

Table 7: Turtle identifications

\begin{tabular}{ll}
\hline Layer & NISP \\
\hline 1 & 1 \\
4 & 25 \\
5 & 21 \\
7 & 1 \\
Total & 48 \\
\hline
\end{tabular}

\section{DATING}

Watom Island apears to present some distinct problems for radiocarbon dating, and there are inconsistencies between the existing dates and the new ones obtained in $2008 / 09$. One potential problem that has been discussed by Petchey \& Ulm (2012) is the effect of upwelling currents on $\Delta \mathrm{R}$ values for marine species and terrestrial species with a marine diet component. More prosaic is the challenge posed by finding datable items in absolutely secure contexts. Two new radiocarbon dates were obtained from secure contexts in SAC as a result of the 2008/2009 excavations (Figure 21). These were calibrated using OxCal v3.10 (Bronk Ramsey 2005). The radiocarbon determinations from all previous excavations have been thoroughly discussed in Anson et al (2005: 16-20, 37-39), and samples from Burials 1 and 3 were redated in 2009 (Petchey et al. 2011). A full review of the past and current radiocarbon dates for the overall Reber-Rakival site will be undertaken in a future publication, and only the new dates and their contexts are discussed here.

The first occupation of the site remains undated, as the previous dates that were thought to be from the first visitations (WK 7370 and ANU 5339, which calibrate to before $2800 \mathrm{BP}$ (Anson et al. 2005)) are now within the cultural sequence. Recent redating of existing samples of human bone from Burials 1 and 3 by Petchey et al. (2011) produced respective dates of 2800-2730 cal BP (Wk15567a and 15567b) and 2670-2640, 2610-2590, 25102350 cal BP (Wk 15568 and NZA 13685). A detailed reconsideration of the stratigraphic context of these burials is required, using the data presented in the present paper, before these dates can be fully interpreted.

No datable material was found in the deepest parts of the sites that were excavated in 2009. The deepest stratigraphically secure new determination is that from Burial 15 , which is dated to between 2500 and $2150 \mathrm{Cal} \mathrm{BP}$ (at $64.8 \%$ probability) (WK 28510 ). This is somewhat at odds with the earlier dates (2800 BP) already mentioned, which by default must be stratigraphically later (as the excavators never reached the level of the top of the Burial 15 grave cut). Burial 10 was stratigraphically higher, and provided a correspondingly younger determination (1930 to $1620 \mathrm{Cal} \mathrm{BP}$ at $68.2 \%$ probability).

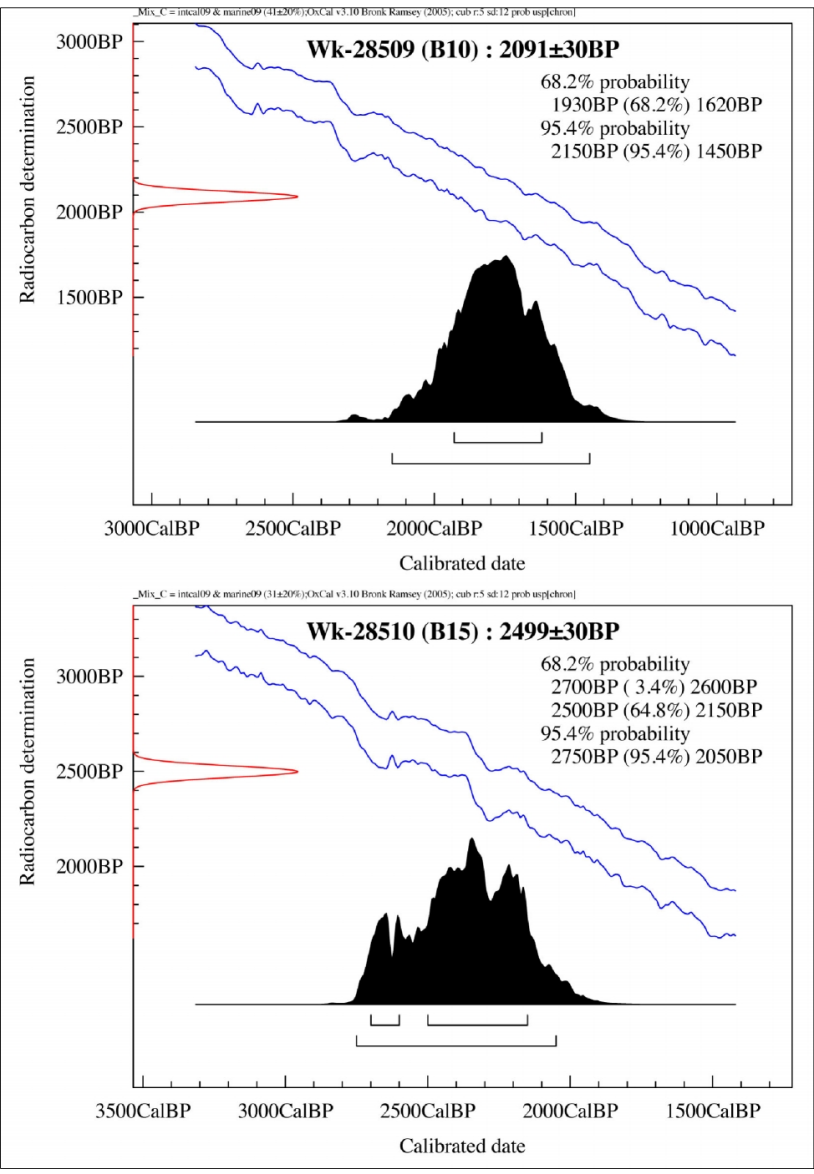

Figure 21: Radiocarbon curves for Burials 10 and 15.

These determinations alone are not enough to confidently re-date the SAC site, but they do highlight the fact that there are issues that need to be addressed.

\section{INTERPRETATION OF THE SAC SITE \& STRATIGRAPHY}

The large area excavated to date at the SAC locality ( 75 $\mathrm{m}^{2}$ as of 2009) allows an increasingly detailed interpretation of the site to be made. The most recent published interpretation of the overall Reber-Rakival site was by Anson, Walter \& Green (2005), who used an Event-Phase Sequence (EPS) model to correlate the stratigraphic sequence with key events and periods in the site history. This EPS model had 13 phases (I to XIII) based on stratigraphic interpretation and radiocarbon determinations of all of the excavations carried out up to 1985 (Anson et al. 2005: 25-35). Table 8 presents a basic overview of this model. 
The EPS model was developed for the entire ReberRakival area drawing on data from the SAC, SDI and SAD locations. The new excavations at SAC confirm the general outline of the sequence but show that human occupation occured earlier than previously identified and reveal additional levels of stratigraphic complexity. The following section reflects on the published Event-Phase Sequence sequence in light of the new SAC data. A fully revised Event Phase Sequence model that draws on all the new Reber-Rakival excavations will be publised separately.

Table 8: Event-Phase Sequence from Anson et al. 2005. $\mathbf{L W L}=$ Late Western Lapita. $\mathbf{P L}=$ Post Lapita

\begin{tabular}{|c|c|c|}
\hline $\begin{array}{l}\text { Event } \\
\text { Phase }\end{array}$ & Description & Date Range \\
\hline I & Creation of beach \& coastal plain & Before cal. $1000 \mathrm{BC}$ \\
\hline II & 0 population to $1^{\text {st }}$ intermittent visits & $\begin{array}{l}\text { cal. } 920 \mathrm{BC} \text { to } 1260 \\
\text { BC }\end{array}$ \\
\hline III & First permanent occupation (LWL) & $\begin{array}{l}\text { cal. } 750 \mathrm{BC} \text { to } 200 \mathrm{BC} \\
\text { or later }\end{array}$ \\
\hline IV & Creation of burial ground at SAC & cal. $720 \mathrm{BC}$ to $560 \mathrm{BC}$ \\
\hline $\mathbf{v}$ & $\begin{array}{l}\text { Stone alignments constructed } \\
\text { around cemetery }\end{array}$ & cal. $20 \mathrm{AD}$ to $260 \mathrm{AD}$ \\
\hline VI & $\begin{array}{l}100 \text { yrs of intermittent to nil occupa- } \\
\text { tion }\end{array}$ & cal. $150 \mathrm{AD}$ to $250 \mathrm{AD}$ \\
\hline VII & $\begin{array}{l}\text { Cyclonic event \& reoccupation (very } \\
\text { LWL to } P L \text { ) }\end{array}$ & cal. $200 \mathrm{AD}$ to $400 \mathrm{AD}$ \\
\hline VIII & $\begin{array}{l}\text { Period of gardening \& palaeosol } \\
\text { formation }\end{array}$ & cal. $330 \mathrm{AD}$ to $620 \mathrm{AD}$ \\
\hline IX & $\begin{array}{l}\text { Main Rabaul volcanic eruption and } \\
\text { ash-fall }\end{array}$ & cal. $540 \mathrm{AD}$ to $650 \mathrm{AD}$ \\
\hline $\mathbf{x}$ & $\begin{array}{l}\text { Re-deposition of ash on Rakival } \\
\text { Beach }\end{array}$ & $8^{\text {th }}$ to $9^{\text {th }}$ century $A D$ \\
\hline $\mathbf{X I}$ & Reoccupation by aceramic groups & $1250 \mathrm{AD}$ \\
\hline XII & $\begin{array}{l}\text { Successive erosion events (volcanic } \\
\text { ash) }\end{array}$ & $\begin{array}{l}\text { ca. } 1400 \mathrm{AD} \text { to } 1800 \\
\text { AD }\end{array}$ \\
\hline XIII & Historic Tolai occupation & \\
\hline
\end{tabular}

Event Phases I - III.

In Anson et al. (2005) the pre-human beach development (Phase I) was equated with Zone D (Layer 7) which was not dated and considered to be sterile. Phase II (intermittent visitation by non-residential groups) was represented by ephemeral activities and dating samples taken from the Zone C2/Zone D interface (Anson et al. 2005: 27), while cooking features, postholes and midden at the lower levels of Zone C2 (Layer 6) were interpreted as signalling the first permanent occupation (Phase III) (Anson et al. 2005: 28).

The more recent excavations show that Layer 7 (Zone D) was not sterile but exhibited cultural modifcation up to $0.8 \mathrm{~m}$ below what Anson et al. (2005) considered to be the top of the natural sand deposits. Thus the excavated SAC sequence commences with Phase II (intermittent visitation), and Phase I (the natural formation of the beach) is no longer considered to be directly represented stratigraphically (water ingress prevented any deeper excavation). Anson et al. (2005: 39, Figure 7) cited two radiocarbon samples that calibrate to before $2800 \mathrm{BP}$ (WK 7370 and ANU 5339) as dating to the period immediately prior to human activity. Stratigraphically, these dates must now be interpreted as falling within Phase II.
Although the actual date of first human activity at SAC is still uncertain, it is earlier than $2800 \mathrm{BP}$ which is the date Anson et al. (2005) took as the terminus post quem for settlement. This date also marks the point at which Mopir obsidian became available again for use in Near Oceania having been buried for nearly a millenium by the Witori eruption of 3600 BP (Torrence 2004). Mopir obsidian appears from Layer 6 at SAC. At this point, therefore, first occupation of Watom can no longer be associated with the reappearance of Mopir obsidian in the regional archaeolgical record. Similarly, there is no evidence of ceramics use by the first visitors at SAC. Phase III (permanent occupation) is represented by Layer 6 (lower Zone C2) which is consistent with Anson et al. (2005).

\section{Event Phases IV \& V}

The 2009 SAC excavation suggests that these two phases; the development of a burial ground (Phase IV) and the construction of stone alignments and other features (Phase V); should be transposed. The first stone alignment to be constructed was Alignment 2, a limestone coral feature which was superseded by Alignment 1 , a mixed volcanic/limestone structure (Figure 11). The 2009 SAC excavation shows that these constructions predate the burial events (previously interpreted as Phase IV). This is actually consistent with the published sections in Green and Anson (1998: 35) which show the alignments originating low in the Layer 6 horizon.

The creation of a burial ground must now be interpreted as Phase V in the sequence. Anson et al. (2005: 30) believed the burial ground was '...pocketed within a confined space of the upper portion of Zone C2.' However, the larger area now excavated at SAC produced burials dug from Layer 6 (lower Zone C2: Burials 14 and 15) through to the top of Layer 5 (upper Zone C2 Burial 13). The stratigraphically highest burial in Layer 5 was Burial 13. Stones sitting vertically in the side of what was probably the grave cut indicate that this burial was cut from the surface of Layer 5 (upper Zone C2), and the grave fill consisted of Layer 5 matrix, so the grave was not cut from Layer 4 (Zone $\mathrm{C} 1$ ). The observation that the burials were cut from throughout Zone $\mathrm{C} 2$ (Layers 5 and 6) refutes Best's (2002: 89) view that all of the burials were intrusive into the Lapita layer (Zone C2) from Layer 4 (Zone C1).

\section{Event Phase VI}

Anson et al. $(2005$; 31$)$ identified a period of about a century of limited activity that was represented stratigraphically across the Reber-Rakival site. At SAC it was represented by the clearly defined surface of Layer 5 (upper Zone C2) which also contained animal (mainly pig) bones with evidence of weathering suggesting a period of exposure. Best (2002:87) has raised the question of whether Layer 5 was disturbed by gardening activities in Layer 4 (Phase VIII). If this happened, the surface of Layer 5 may have been truncated, undermining the stratigraphical argument for a period of abandonment. Our observations are that the Layer 4/Layer 5 interface was 
quite undulating, as one would expect of a surface that had been occasionally disturbed from above. The presence of human bone fragments and some Lapita sherds in Layer 4, together with the exposure of stones in the Burial 13 grave cut, suggests that some truncation and pitting of Layer 5 did occur, but the extremely abrupt change in the matrix of the two layers indicates that there was only limited intermixing of the two layers.

We support the Anson et al. (2005) view that there was little activity at SAC at this period, but suggest that the period of inactivity was less than a century. Smith (2000: 143), for example, observed that the weathered bones showed 'fine hair line cracks which are characteristic of bones in the early stages of weathering,' and that 'there were no examples of splitting or exfoliation to indicate that the bones had been subjected to more advanced weathering'.

\section{Event Phases VII to XIII}

The 2009 SAC excavations generally support the existing interpretations of these phases, but with some revision of Phase X, the redeposit of volcanic ash on the beach from the hillslopes above after the Rabaul eruption (Phases IX \& XII). The 2009 results of the SAC excavation suggest that there was only limited redeposition of volcanic ash in this phase, and instead a great deal of reworking of the primary (Phase IX) ashfall. In effect Layer 2 is culturally modified ash rather then naturally redeposited ash, and a cultural layer in its own right. The main implication of this is that there was possibly a rapid reoccupation of the site (Phase XI) with a great deal more human activity than that described by Anson et al. (2005: 34), thus altering the timing and intensity of Phases X and XII. This postashfall reoccupation of SAC has distinct parallels with the initial Layer 7 human occupation whereby initial activity consisted of pits and postholes dug into a largely sterile soil, but with remarkably little artefactual or midden material being deposited.

\section{CONCLUSIONS}

As a result of the increased area of the SAC locality that has now been excavated, a more detailed picture of the stratigraphy and nature of the site has emerged. This has allowed a refinement of the original stratigraphic interpretation to be made, as well as clarification of the basic sequence of Lapita-era layers. In particular the original 4 Zone interpretation has been replaced by a 7 Layer interpretation, within which the key change has been the extension and increased complexity of the cultural sequence.

Cultural activity has been identified up to $0.8 \mathrm{~m}$ deeper than in previous excavations, which includes the excavation of Burial 15 from beneath the 1985 excavation. What was previously described as Zone D sterile sand is now described as Layer 7, a cultural layer with human activity occurring on a previously unoccupied beach. This revision in turn suggests an earlier date of first occupation is more likely than previously published, and the dates once thought to relate to first settlement are now within the cultural sequence. The first human presence was ac- companied by neither obsidian nor ceramics, raising interesting questions as to whether or not the first visitors possessed these.

Within the main occupation layers, burials have now been identified as being cut from within the entire Layer 5 \& 6 (Zone C2) occupation period, from the top of Layer 5 (the top of upper Zone C2) down to Layer 6 (lower Zone $\mathrm{C} 2$ ). With regard to the spatial distribution of the burials, the stone alignments previously interpreted as delineating a cemetery no longer appear to be associated with this activity, or at least the activity moved outside the enclosed area. The stone alignments are also now interpreted as being earlier in the stratigraphic sequence than previously described. Increasing evidence of considerable industrial activity has also been observed within the period of Lapita occupation, including abraders, grindstones and worked shell.

Finally, the upper, disturbed, volcanic ash layer (Layer 2, previously Zone B1) is now interpreted as culturally reworked/redeposited ash rather than largely redeposited ash, and was the site of a great deal of human activity as people re-occupied the post-ashfall site.

However, a number of key aspects of the site interpretation remain unchanged. With regard to the important issue of the period of human interments, the burials are all within Layers 5 and 6 (Zone C2), and no burials were cut down from Layer 4 (Zone C1). The stratigraphic context of Burial 13 and presence of fragmented human bone and some Lapita sherds in Layer 4 suggests that some truncation of Layer 5 (Zone C2) did happen, but the Burial 13 grave fill was Layer 5 matrix which indicates that the burial was cut from within that layer, not from Layer 4 above. The clear stratigraphic association of the burials with Lapita ceramic fragments remains unchanged. The discovery of a number of unweathered and stratigraphically consistent Lapita ceramic sherds in Layer 5 in 2009 indicates that these sherds are in primary context, and had not been redeposited by later activities. Within the overall site stratigraphy, Layer 4 (Zone C1) effectively seals the Layer 5 (Zone C2) context, and although some intermixing did occur due to gardening activity, this was not enough to cause major mixing of the two quite distinct contexts. Consistencies in the stratigraphic distribution and relative proportions of Admiralties, Talasea and Mopir sourced obsidian also support this security of the Layer 4-Layer 5 separation.

The Rabaul volcanic ash effectively completely sealed the Lapita occupations of the site in a single catastrophic event. Although some limited disturbance from Layer 2 right down through the ash (Layer 3 ) to the buried cultural soil horizon (Layer 4) has now been found, this was only in one location and does not alter the overall interpretation of the site.

With regard to Best's (2002) discussion of the ReberRakival site and his opinion that all of the SAC burials were intrusive into Zone C2 (Layers 5 \& 6), the 2008/09 excavations have provided more detailed evidence for the debate to be revisited. The Burial 13 grave cut was almost certainly truncated by activities associated with Layer 4 
(Zone $\mathrm{C} 1$ ), and in part supports Best's suggestions. However, as already observed the Burial 13 grave fill was Layer 5 matrix, not Layer 4 matrix (nor a mixture of the two), so it was cut within Layer 5. In addition, Burial 15 (which had a well-defined grave cut) was cut from well within Layer 6 (lower Zone C2), and supports the arguments of Anson et al. (2005) that the burials were completely within Zone C2 (Layers 5 \& 6). Further work on obtaining new radiocarbon dates and refining and recalibrating old dates is underway to attempt to further address these issues.

In general, the enlarged excavation area at the SAC locality has identified an increased complexity within the site, and has allowed the stratigraphic sequence to be lengthened and refined. This not only answers some old questions, such as the association of the burials with Lapita-era occupation, but also poses new questions such as whether the first occupants possessed ceramics or obsidian, the date of this first occupation, and the date and intensity of the post-volcanic eruption reoccupation of Watom Island.

\section{ACKNOWLEDGEMENTS}

The late Herman Mandui of the Papua New Guinea National Museum gave permission and actively facilitated the project. Matthew Levesley, of the University of Papua New Guinea, provided logistical support. Paul Kop, also from the museum participated in the 2009 excavation season. Steve Saunders of the Rabaul Vulcanological Observatory provided assistance in Rabaul. The Rakival villagers provided hospitality and labour for the excavations, and Anton Lome, Ludwik Tode and Penticost Lome must be particularly thanked for their assistance. Kasey Robb and Ben Shaw of the University of Otago participated in the excavation. The undertaking of this excavation was made possible through an University of Otago Research Grant, an Australian Pacific Science Foundation grant and through financial and other assistance from the Otago Museum in Dunedin. We would also like to thank the two anonymous referees for their suggestions.

\section{REFERENCES}

Anson, D. 1983. Lapita Pottery of the Bismark Archipelago and its Affinities. Unpublished PhD thesis, University of Sydney, Australia.

Anson, D. 1986. Lapita Pottery of the Bismark Archipelago and its Affinities. Archaeology in Oceania 21: 157-165.

Anson, D. \& Green, R.C. 2000. Excavations at Kainapirina (SAC), Watom Island, Papua New Guinea. New Zealand Journal of Archaeology, 2000, Vol. 20 (1998), pp. 29-94.

Anson, D., Walter, R., Green, R.C. 2005. A Revised and Redated Event Phase Sequence for the Reber-Rakival Lapita Site, Watom Island, East New Britain Province, Papua New Guinea. University of Otago Studies in Prehistoric Anthropology No. 20.

Bedford, S., M. Spriggs, and R. Regenvanu, 2006. The Teouma Lapita site and the early human settlement of the Pacific Islands. Antiquity, 80: p. 812-828.
Bedford S, M. Spriggs, H. Buckley, F. Valentin and R. Regenvanu, 2009. The Teouma Lapita site, South Efate, Vanuatu: a summary of three field seasons (2004-2006). In P. Sheppard, T. Thomas and G. Summerhayes (eds), Lapita: Ancestors and Descendants. New Zealand Archaeological Association Monograph 28. Pp: 215-234.

Best, S. 2002. Lapita: A View From the East. New Zealand Archaeological Association Monograph 24.

Bronk Ramsey, C., 2005. OxCal Program v3.10. Radiocarbon Accelerator Unit, University of Oxford.

Buikstra and Ubelaker 1994. Standards for data collection from human skeletal remains. Fayetteville: Arkansas Archaeological Survey.

Butler, V.L. 1988. Lapita fishing strategies: the faunal evidence. In, Kirch, P.V. and Hunt, T.L. (eds.) Archaeology of the Lapita complex: a critical review. Seattle.Thomas Burke Memorial Washington State Museum Research Report No.5, Burke Museum, pp 99-115.

Chen, Y. 2012. Time of Transition: Patterns of Obsidian Exchange and Utilization during the Lapita and Post-Lapita periods on Watom Island, Papua New Guinea. M.A. Thesis, Department of Anthropology \& Archaeology, University of Otago.

Claassen, C. 1998. Shells, Cambridge, Cambridge University Press.

Garling, S. J. 2007. Post-Lapita Evolutions or Revolutions? Interaction and Exchange in Island Melanesia: The View from the Tanga Islands. PhD Thesis, Department of Archaeology and Natural History, Australian National University, Canberra.

Grayson, D.K. 1984. Quantitative zooarchaeology: topics in the analysis of archaeological faunas, Orlando, Academic Press.

Green, R.C. 2000. An Introduction to Investigations on Watom Island, Papua New Guinea. New Zealand Journal of Archaeology, 2000, Vol. 20 (1998), pp. 5-27.

Green, R. C., D. Anson and J. Specht 1989. The SAC burial ground, Watom Island, Papua New Guinea. Records of the Australian Museum 41(3): 215-221.

Green, R.C. and Anson, D. 1998. Excavations at Kainapirina (SAC), Watom island, Papua New Guinea. New Zealand Journal of Archaeology 94.

Houghton, P. 1989. Watom: the people. Records of the Australian Museum 41(3): 223-233.

Kinaston R.L., Anson D., Petchey P., Walter R., Robb K., Buckley, H. 2015. Late-Lapita diet and subsistence strategies on Watom Island, Papua New Guinea: new stable isotope evidence from humans and animals. American Journal of Physical Anthropology 157: 30-41

Kinaston, R.L., Bedford, S.B., Spriggs, M., Anson, D., and Buckley, H. 2016. Is there a 'Lapita diet'? A comparison of Lapita and post Lapita skeletal samples from four pacific island archaeological sites. In M. Oxenham and $\mathrm{H}$. Buckley (eds). The Routledge Handbook of Bioarchaeology of Southeast Asia and the Pacific Islands. Taylor Francis. London. Pp. 427-461.

Leach, B.F. 2006. Fishing in Pre-European New Zealand, New Zealand Journal of Archaeology special Publication/Archaeofauna Vol. 15. 
Meyer, O.1909a. Funde Prahistorischer Topferei und Steinmesser auf Vautom, Bismark Archipel. Anthropos 4 (Analecta et Additamenta): 251-2.

Meyer, O. 1909 b. Funde Prahistorischer Topferei und Steinmesser auf Vautom, Bismark Archipel. Anthropos 4 (Analecta et Additamenta): 1093-1095.

Meyer, O. 1910. Funde von Menschen-und Tierknochen, von prahistorischer Topferei und Steinwarkzeugen auf Vautom, Bismark Archipel. Anthropos 5 (Analecta et Additamenta): 1160-1.

Petchey, F., Spriggs, M., Leach, F., Seed, M., Sand, C., Pietrusewsky, M., Anderson, K. 2011. Testing the Human Factor: Radiocarbon Dating the First Peoples of the South Pacific. Journal of Archaeological Science, 38(1): 29-44.

Petchey, F., Ulm, S. 2012. Marine Reservoir Variation in the Bismark Region: An Evaluation of Spatial and Temporal Change in $\Delta \mathrm{R}$ and $R$ Over the Last 3000 years. Radiocarbon, 54 (1): 45-58.

Petchey, P.G. 2015. Second World War Japanese Defences on Watom Island, Papua New Guinea. Journal of Conflict Archaeology, 10 (1): 29-51.

Pietrusewsky, M. 1989. A study of the skeletal and dental remains from Watom Island and comparisons with other Lapita people. Records of the Australian Museum 41: 235-292.

Pietrusewsky, M., Buckley, H., Anson, D., Douglas, M.T. 2014. Polynesian origins: a biodistance study of mandibles from the Late Lapita site of Reber-Rakival (SAC), Watom Island, Bismarck Archipelago.' Journal of Pacific Archaeology. 5(1): p. 1-20.

Reitz, E.J. and Wing, E.S. 2008. Zooarchaeology, Leiden, Cambridge University Press.

Serjeantson, D. 2009. Birds, New York, Cambridge University Press.

Sande, C. 1998. Archaeological Report on Localities WKO013A and WKO013B at the Site of Lapita (Kone, New Caledonia). Journal of the Polynesian Society 107: 7-34.

Shaw, B., H. Buckley, G. Summerhayes, D. Anson, S. Garling, F. Valentin, H. Mandui, C. Stirling and M. Reid 2010. Migration and mobility at the Late Lapita site of ReberRakival (SAC), Watom Island using isotope and trace element analysis: a new insight into Lapita interaction in the Bismarck Archipelago. Journal of Archaeological Science 37: 605-613.

Slater, J. N. 2008. A Cutting Analysis: A Study of Obsidian Resource Maximisation from a Lapita Assemblage on Watom Island. B.A. (Hons) Thesis, Department of Anthropology \& Archaeology, University of Otago.

Smith, I.W.G. 2000. Terrestrial Fauna from Excavations at the Kainapirina (SAC) Locality, Watom Island, Papua New Guinea. New Zealand Journal of Archaeology, Vol. 20 (1998), pp. 137-147.

Specht, J. 1968. Preliminary Report on Excavations on Watom Island. Journal of the Polynesian Society 77(2): 117-134.

Specht, J. 2003. Watom Island and Lapita: Observations on the Reber-Rakival Localities. In C. Sand (ed.) Pacific Archaeology: Assessments and Prospects. Proceedigs of the International Conference for the $50^{\text {th }}$ Anniversary of the First Lapita Excavation: Kone-Noumea 2002. Les Cahiers de l'Archeologie en Nouvelle-Caledonie 15: 121-134. Noumea: Service des Musees et du Patrimoine.

Summerhayes, G. 2010. The emergence of the Lapita Cultural Complex in the Bismark Archipelago. In Sand, C. \& Bedford, S. (eds) Oceanic Ancestors. Somology Editions D'Art, Paris

Torrence, R. 2004. Now you see it, now you don't: changing obsidian source use in the Willaumez Peninsula, Papua New Guinea. In J. Cherry, C. Scarre and S. Shennan (eds), Explaining social change: studies in honour of Colin Renfrew. McDonald Institute Monographs, Cambridge, pp. 115-125. 